\title{
Behaviours of antiviral Oseltamivir in different media: DFT and SQMFF calculations
}

\author{
Mohammad Vakili $^{1}$ Elida Romano ${ }^{2} \cdot$ Vahidreza Darugar $^{1} \cdot$ Silvia Antonia Brandán $^{2}$ (I)
}

Received: 17 August 2021 / Accepted: 20 October 2021 / Published online: 23 November 2021

(c) The Author(s), under exclusive licence to Springer-Verlag GmbH Germany, part of Springer Nature 2021

\begin{abstract}
The synthetic cyclohexenecarboxylate ester antiviral Oseltamivir $(\mathrm{O})$ have been theoretically studied by B3LYP/6$311++\mathrm{G}^{* *}$ calculations to estimate its reactivity and behaviour in gas and aqueous media. The most stable structure obtained in above media is consistent with that reported experimental for Oseltamivir phosphate. The solvation energy value of $(\mathrm{O})$ in aqueous media is between the predicted for antiviral Idoxuridine and Ribavirin. Besides, $(\mathrm{O})$ containing a $\mathrm{NH}_{2}$ group and $\mathrm{NH}$ group reveals lower solvation energy compared with other antiviral agents with an $\mathrm{NH}_{2}$ group, such as Ribavirin, Cidofovir, and Brincidofovir. Atomic charges on $\mathrm{N}$ and $\mathrm{O}$ atoms in acceptors and donor groups reveal different behaviours in both media, while the natural bond orbital (NBO) studies show a raised stability of $(\mathrm{O})$ in aqueous solution. This latter resulted is in concordance with the lower reactivity evidenced in water. Frontier orbital studies have revealed that $(\mathrm{O})$ in gas phase has a very similar gap value to antiviral Cidofovir used against the ebola disease, while Chloroquine in the two media are more reactive than $(\mathrm{O})$. This study will allow to identify $(\mathrm{O})$ by using vibrational spectroscopy because the 144 vibration modes expected have been assigned using the harmonic force fields calculated from the scaled mechanical force field methodology (SQMFF). Scaled force constants for $(\mathrm{O})$ in the mentioned media are also reported for first time. Due to hydration of the $\mathrm{C}=\mathrm{O}$ and $\mathrm{NH}_{2}$ groups by solvent molecules, the calculations in solution produce variations not only in the IR wavenumbers bands, but also in their intensities.
\end{abstract}

Keywords Oseltamivir $\cdot$ Structural properties $\cdot$ Force fields $\cdot$ Vibrational study $\cdot$ DFT calculations

\section{Introduction}

Chemically, Oseltamivir is a synthetic cyclohexenecarboxylate ester with antiviral activity whose IUPAC name is ethyl $(3 R, 4 R, 5 S)$-4-acetamido-5-amino-3-pentan3-yloxycyclohexene-1-carboxylate [1-19]. Oseltamivir is used in health sciences for the treatment of influenza $A$ and influenza $B$ [5-8]. Lindegårdh et al. have reported the use of HPLC for evaluation of Oseltamivir, while the same technique is used in other study for the determination of Oseltamivir phosphate and generic versions $[1$,

Silvia Antonia Brandán

sbrandan@fbqf.unt.edu.ar

1 Department of Chemistry, Faculty of Science, Ferdowsi University of Mashhad, Mashhad, Iran

2 Cátedra de Química General, Instituto de Química Inorgánica, Facultad de Bioquímica. Química Y Farmacia, Universidad Nacional de Tucumán, Ayacucho 471, (4000) San Miguel de Tucuman, Tucumán, Argentina
2]. Spectrofluorimetric and rapid capillary electrophoresis methods are also employed for the determination of Oseltamivir phosphate in capsules and generic versions [3, 4]. The most used method is the vibrational spectroscopy, including the SERS technique, because these methods are fast and highly reliable $[9,11,15-17]$. The quantification of Oseltamivir by Raman spectroscopy and the combination of the SERS technique with functional gold nanoparticles allow rapid identification of the Oseltamivir-resistant H1N1 virus, as was recently published $[16,17]$. To assign all vibrational bands, IR and Raman, bands of Oseltamivir, first is necessary to determinate its most stable structure. So far, configurations and conformations of (-)-Oseltamivir using a multi-chiroptical approach [12] and studies in silico on stereoisomers of Oseltamivir [14] were reported, but the vibrational assignments of Oseltamivir are not reported yet. Hence, the objectives here are (i) to analyze the most stable structure of Oseltamivir in gas phase and water, as solvent, at B3LYP level using 6-311++ $\mathrm{G}^{* *}$, as basis set [20, 21]; (ii) to evaluate charges of atoms, electrostatic potentials, 
acceptors-donor interactions, topological properties, reactivity, and behavior of Oseltamivir as an isolated molecule and, then, to compare with the values in solution; and (iii) to use the scaled quantum mechanical force field (SQMFF) methodology and the Molvib, as a Fortran program, to assign the observed bands in its available IR spectrum. To achieve this latter purpose, scaling factors together and definitions of normal internal coordinates are necessary [22-25]. Here, calculations and optimizations in water were performed with the polarized continuum method (PCM) and the universal solvation model [26-28]. Here, the above level of calculations combined with the harmonic force fields is a very good tactic to assign experimental bands to vibration modes [29-33]. To conclude, comparisons of predicted properties for Oseltamivir which reported for antiviral agents are presented because the existence of donors and acceptor groups in the structure is important parameters in a pharmacological drug, as proposed by Veber and Lipinski [32-43].

\section{Material and methods}

Configurational and conformational studies of Oseltamivir together with analysis of its stereoisomers were already reported by Górecki and by Hajzer et al. [12, 14], respectively and, for these reasons, in this work, the most stable structure was directly used to optimize Oseltamivir in two phases, gas and water as solvent, at B3LYP/6-311++G** level of DFT and the Gaussian program [44]. The optimizations in solution were done with the integral equationformalism polarizable continuum (IEF-PCM) and universal solvation methods [26-28]. Then, the corrected solvation energy were obtained from the subtract of the energies between soluttgv6ion and gas phase, while the energies due to the non-electrostatic term were obtained from the calculations in solution [44]. The volume changes were obtained with the Moldraw program at the same level of calculations [45]. The natural bond orbital (NBO) and atoms in molecules (AIM) 2000 programs were used to predict different types of interactions, charges, electrostatic potentials, acceptor-donor interactions, and topological properties [46-48]. The molecular electrostatic potentials (MEP) were achieved from atomic Merz-Kollman (MK) charges derived from semiempirical methods [49] while with the GaussView program were obtained graphs of mapped surfaces [50]. To analyze possible activities and behaviours of Osetamivir in the aforesaid phases, the differences between the border orbitals, named gap, and some important descriptors calculated from known equations [29-33, 36, 51] were analyzed. Besides, the ${ }^{1} \mathrm{H}-,{ }^{13} \mathrm{C}-\mathrm{NMR}$, and electronic spectra of Oseltamivir in aqueous solution were obtained with the Gauge-Independent Atomic Orbital (GIAO) method and the time-dependent DFT calculations (TD-DFT) [52], respectively. The vibrational study of Oseltamivir was performed in both media with the SQMFF methodology and the Molvib program by using scaling factors and the calculated harmonic force fields [22-25]. In the normal internal coordinate's analysis, the $\mathrm{NH}_{2}$ and $\mathrm{CH}_{3}$ groups were considered with $C_{2 v}$ and $C_{3 v}$ symmetries, respectively, while only potential energy distribution (PED) contributions $\geq 10 \%$ were employed in the assignments. Here, the theoretical Raman spectra predicted in above-mentioned media in activities were changed to intensities with convenient equations [53]. All of the mentioned calculations obtained at B3LYP/6-311+ + $\mathrm{G}^{* *}$ level of DFT.

\section{Results and discussion}

\section{Optimizations in gas and aqueous solution}

The more stable structure of Oseltamivir was proposed by Marcin Górecki [54] and was optimized in above phase at the above-mentioned level. This structure is shown in Fig. 1, while Table 1 indicates the total energy uncorrected and corrected by zero point vibrational energy (ZPVE), dipole moments, and volumes calculated for Oseltamivir in both media. In that table are also included the permittivity's values of two media. The analyses of results demonstrate that in water the dipole moment value of Oseltamivir increases while a contraction in the volume is observed due to its hydration. The dipole moment vectors are located from centre ring with direction outside as can be seen in the superior graphic of Figure S1, see supplementary materials. The corrected solvation energy value $(\Delta \mathrm{Gc})$ of Oseltamivir determined at the same level of calculations is shown in Table 2. The predicted value for Oseltamivir $(-127.37 \mathrm{~kJ} /$ mol) is most negative (slightly higher) than the antiviral Idoxuridine $(-124.50 \mathrm{~kJ} / \mathrm{mol})$ but lower than antiviral Ribavirin $(-141.85 \mathrm{~kJ} / \mathrm{mol})[40,41]$, as observed in Table 3 . The latter table shows comparisons between the value of Oseltamivir and other predicted for antiviral agents by the above calculated level of theory. Structures of compared antivirals agents including the corresponding to Oseltamivir are presented in Figure S2, see supplementary material. The different acceptor and donor groups of $\mathrm{H}$ bonds justify the different values of solvation energy. The mentioned values are also compared with the corresponding to Oseltamivir phosphate calculated in this work in aqueous solution $(-121.13 \mathrm{~kJ} / \mathrm{mol})$. Therefore, Oseltamivir presents lower value than Ribavirin, Cidofovir, and Brincidofovir because this antiviral species has one $\mathrm{NH}_{2}$ group and one $\mathrm{N}-\mathrm{H}$ bond, while the other species have only one $\mathrm{NH}_{2}$ group, but present a greater amount of hydroxyl groups or oxygen with a single NH bond. Figure 2 shows the solvation energy values increase as acceptor and donor groups are added in the 
Fig. 1 Molecular structure of the most stable conformer of Oseltamivir and atoms numbering

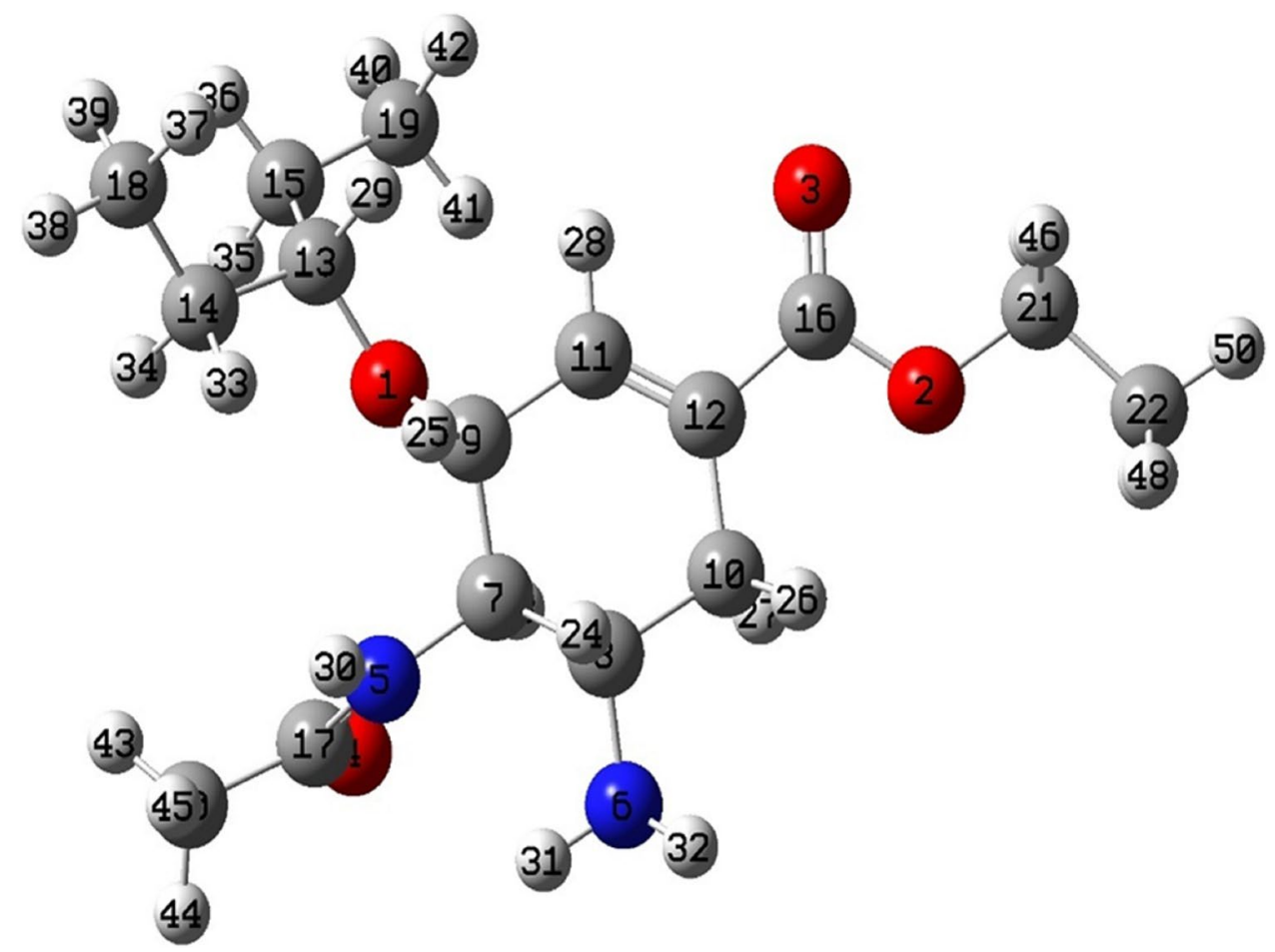

Table 1 Calculated total and corrected by ZPVE energies $(E)$, dipole moments $(\mu)$, and volumes $(V)$ of Oseltamivir in gas phase and aqueous, solutions by using B3LYP/6-311+ + G** level of theory. Permittivity's $(\varepsilon)$ values of two media are also included

\begin{tabular}{llllll}
\hline \multicolumn{2}{l}{ Oseltamivir } \\
\hline Medium & $E$ (Hartrees) & $E$ ZPVE & $\mu(\mathrm{D})$ & $V\left(\AA^{3}\right)$ & $\varepsilon$ \\
\hline Gas & -1037.2860 & -1036.8534 & 5.13 & 353.5 & 1 \\
Water & -1037.3206 & -1036.8876 & 9.63 & 350.4 & 78.3553 \\
\hline
\end{tabular}

structures of antiviral agents. Note that the solvation energy value of Oseltamivir is slightly higher than Oseltamivir phosphate.

\section{Geometries in both media}

To obtain an accurate vibrational analysis, a good structural study is essential and, hence, the theoretical parameters calculated for Oseltamivir were compared with the experimentally determined for Oseltamivir phosphate [55] by Naumov et al. who determined two cationic structures present in the salt crystal, which they called cation 1 and cation 2 . Table 4 indicates the optimized geometry for this compound in two media. Here, to evaluate the optimization achieved, the agreement between the optimized structural parameters with the experimental reported in the literature was considered
Table 2 Corrected solvation energy $\left(\Delta G_{C}\right)$ in $\mathrm{kJ} / \mathrm{mol}$ and volumes variations $(\Delta V)$ of Oseltamivir in gas phase and aqueous solution

\begin{tabular}{llll}
\hline B3LYP/6-311++ ${ }^{* *}$ method & & \\
\hline$\Delta G_{\text {un }}^{\#}$ & $\Delta G_{\text {ne }}$ & $\Delta G_{C}$ & $\Delta V\left(\AA^{3}\right)$ \\
\hline-89.71 & 37.66 & -127.37 & -3.1 \\
\hline
\end{tabular}

$\Delta G_{u n}{ }^{\#}$ uncorrected, $\Delta G_{n e}$ non-electrostatic terms

[55], using the mean square deviation (RMSD) values. It is stated that the bond lengths and bond angles indicate low RMSD values, which determines a good approximation to the proposed structure. The value of RMSD for bond lengths are very small (between 0.0032 and $0.0045 \AA$ ); the lowest value is presented in aqueous solution and the best correlation with cation 2 , while in gas phase presents better correlation with cation 1 . In the case of bond angles values, in both phases present a good correlation with cation 1, showing low RMSD values (between 0.32 and $0.35^{\circ}$ ). If the dihedral angles are estimated, the lowest RMSD values are $34.09^{\circ}$ in PCM compared to cation 2 and $39.60^{\circ}$ for gas compared to cation 1 . The dihedral angles related to the ethyl groups attached to the tertiary carbon bound to oxygen (C13) present a better correlation with cation 1 , whereas the greatest variations are obtained in the dihedral angles involving the carbon atoms of carbonyl group (C16 and C17). 
Table 3 Solvation energies $\left(\Delta G_{C}\right.$ in $\left.\mathrm{kJ} / \mathrm{mol}\right)$ and numbers of $\mathrm{N}-\mathrm{H}$ and $\mathrm{O}-\mathrm{H}$ groups and $\mathrm{N}$ and $\mathrm{O}$ atoms present in 13 antiviral species in aqueous solution by using the hybrid B3LYP/6-311+ + G** level of theory
Fig. 2 Total number of acceptor and donor groups of antiviral agents as function of corrected solvation energy values compared with the corresponding to Oseltamivir by using B3LYP/6$311++\mathrm{G}^{* *}$ level of theory

\begin{tabular}{|c|c|c|c|c|c|c|c|c|c|c|c|}
\hline No & Species & $\Delta G_{C}$ & $\mathrm{~N}-\mathrm{H}$ & $\mathrm{NH}_{2}$ & $\mathrm{O}-\mathrm{H}$ & $\mathrm{O}$ & $\mathrm{C}=\mathrm{O}$ & $\mathrm{N}$ & Total & Groups & Rings \\
\hline 1 & Isothiazol $^{\text {b }}$ & -37.51 & 1 & & & & & 2 & 3 & $\mathrm{SH}, \mathrm{C} \equiv \mathrm{N}$ & R5, R6 \\
\hline \multirow[t]{2}{*}{2} & $\mathrm{~S}(-)$ Chloroquine $^{\mathrm{c}}$ & -55.07 & 1 & & & & & 3 & 4 & $\mathrm{Cl}$ & 2 R6 \\
\hline & $\mathrm{R}(+)$ Chloroquine $^{\mathrm{c}}$ & -59.91 & 1 & & & & & 3 & 4 & $\mathrm{Cl}$ & 2 R6 \\
\hline 3 & Niclosamide $^{\mathrm{d}}$ & -78.43 & 1 & & 1 & 4 & 1 & 2 & 9 & $2 \mathrm{Cl}, \mathrm{NO}_{2}$ & 2 R6 \\
\hline 4 & Zalcitabine $^{\mathrm{k}}$ & -78.92 & & 1 & 1 & 3 & 1 & 3 & 9 & & R5, R6 \\
\hline 5 & Emtricitabine $^{\mathrm{e}}$ & -100.88 & & 1 & 1 & 3 & 1 & 3 & 9 & $\mathrm{~F}$ & R5, R6 \\
\hline 6 & Trifluridine $^{\mathrm{f}}$ & -113.85 & 1 & & 2 & 5 & 2 & 2 & 12 & $\mathrm{CF}_{3}$ & R5, R6 \\
\hline 7 & Thymidine $^{f}$ & -116.16 & 1 & & 2 & 5 & 2 & 2 & 12 & $\mathrm{CH}_{3}$ & R5, R6 \\
\hline 8 & Oseltamivir phosphate $^{\mathrm{a}}$ & -121.13 & 1 & 1 & 3 & 8 & 2 & 2 & 17 & $\mathrm{H}_{3} \mathrm{PO}_{4}$ & R6 \\
\hline 9 & Idoxuridine ${ }^{g, \#}$ & -124.50 & 1 & & 2 & 5 & 2 & 2 & 12 & I & R5, R6 \\
\hline 10 & Oseltamivir $^{\mathrm{a}}$ & -127.37 & 1 & 1 & & 4 & 2 & 2 & 11 & & R6 \\
\hline 11 & Ribavirin $^{\mathrm{h}}$ & -141.85 & & 1 & 3 & 5 & 1 & 4 & 14 & & $2 \mathrm{R} 5$ \\
\hline 12 & Cidofovir $^{\mathrm{i}}$ & -169.21 & & 1 & 3 & 6 & 1 & 3 & 14 & $\mathrm{H}_{2} \mathrm{PO}_{3}$ & R6 \\
\hline 13 & Foscarnet $^{\mathrm{j}}$ & -219.64 & & & 12 & 5 & 2 & & 19 & $3 \mathrm{Na}, \mathrm{PO}_{3}$ & \\
\hline 14 & Brincidofovir $^{\mathrm{i}}$ & -227.34 & & 1 & 2 & 7 & 1 & 3 & 15 & $\mathrm{HPO}_{3}$ & R6 \\
\hline
\end{tabular}

${ }^{\mathrm{a}}$ This work

${ }^{\mathrm{b}}$ From Ref[36]

${ }^{c}$ From Ref[31]

${ }^{\mathrm{d}}$ From Ref[32]

${ }^{\mathrm{e}}$ From Ref[37]

${ }^{\mathrm{f}}$ From Ref[38]

${ }^{\mathrm{g}}$ From Ref[39]

${ }^{\mathrm{h}}$ From Ref[40]

${ }^{\mathrm{i}}$ From Ref[35]

${ }^{\mathrm{j}}$ From Ref[41]

${ }^{k}$ From Ref[42]

\#Idoxuridine calculated by using B3LYP/3-21G* calculations

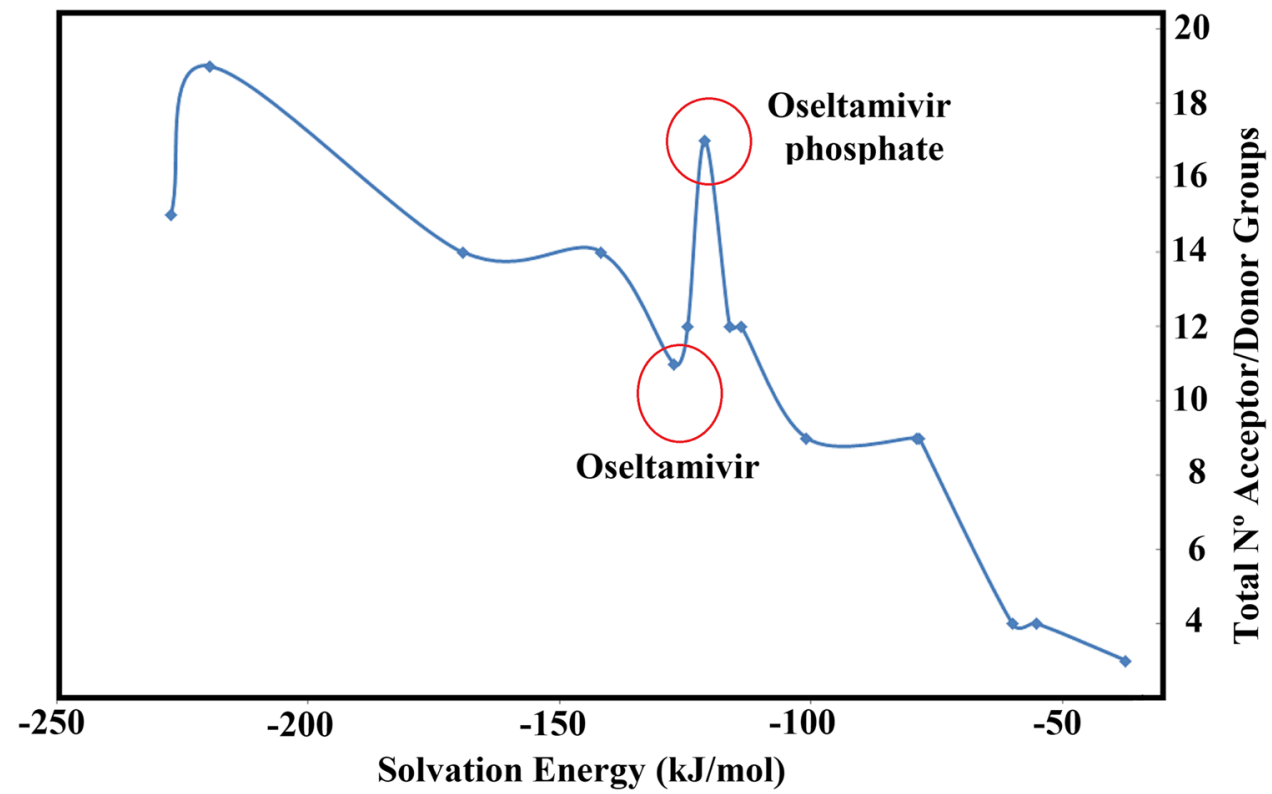




\section{Charges, electrostatic potential, and bond order studies}

To explain the behaviours of species in different media, properties such as the charge of atoms, molecular electrostatic potentials, and bond orders (BO) were determined. The behaviours of species in different media can be analysed by the mentioned parameters. Hence, atomic MerzSingh-Kollman (MK), Mulliken, and natural population atomic (NPA) charges together with MEP and BO, revealed as Wiberg indices, were obtained for Oseltamivir only on $\mathrm{O}$ and $\mathrm{N}$ atoms and, in the case of $\mathrm{C}$ atoms, only for those attached to nitrogen atoms because these atoms belong to acceptors and donors groups of $\mathrm{H}$ bonds. According to analyzing the NPA charges in both media, the most negative value is obtained on the $\mathrm{N} 6$ of $\mathrm{NH}_{2}$ group, while Mulliken charges show the $\mathrm{C} 7$ atom with the most negative value, followed by the N6 atom in both media, as shown in Table 5 . The full analysis of Table 5 indicates that the charges of $\mathrm{O} 2$, $\mathrm{O} 3$, and $\mathrm{O} 4$ atoms in the both media are negative values and the most negative value is observed for $\mathrm{O} 4$ in all cases, but the Mulliken charges on $\mathrm{O} 1$ is positive values in both phases. Also, the Mulliken charges on N5 atoms in the mentioned media have positive values, while MK and NPA charges display negative values on this atom in both media. Figure 3 shows the different behaviours of MK (light gray line), NPA (orange line), and Mulliken charges (light blue line) on $\mathrm{O}, \mathrm{N}$, and $\mathrm{C}$ atoms of Oseltamivir in gas phase. Here, we quickly observed the discrepancy in Mulliken charges on O1 and N5 atoms, previously mentioned. Also, in aqueous solution, the same tendencies are observed.

The MEP values for Osaltimivir in gas and water have been calculated at the similar level and by using the MerzSingh-Kollman scheme (Table 6). Similar MEP values can be observed in the two media. The molecule's charge distribution can be represented by mapped electrostatic potential surfaces whose colorations determine how molecules interact with each other at reactive sites. These distributions of charges in this compound are very well observed on the mapped surfaces represented with the GaussView program [50]. Thus, red, blue, and green colours on the MEP surfaces show respectively different nucleophilic, electrophilic, and inert regions of reactivity (see Fig. 4). Hence, the graphics in both media show the three colours in the same regions. Hence, on free pairs of $\mathrm{N}$ and $\mathrm{O}$ atoms are observed strong red colours and light blue colours on the $\mathrm{H} 31$ and $\mathrm{H} 32$ atoms of $\mathrm{NH}_{2}$ group, on the $\mathrm{H} 30$ atom of $\mathrm{NH}$ group, and on the $\mathrm{H}$ atoms of $\mathrm{CH}_{3}$ group. Then, nucleophilic sites are characterized by red colour and electrophilic sites by blue colour, while the regions with green colour are inert sites. From these MEP surfaces, we clearly observed that carbonyl group and imino/amino groups are the favourable sites for
Table 4 Comparison of calculated geometrical parameters for the Oseltamivir in gas and water solutions compared with the corresponding experimental ones in the solid phase

\begin{tabular}{|c|c|c|c|c|}
\hline \multicolumn{5}{|c|}{$\mathrm{B} 3 \mathrm{LYP} / 6-311++\mathrm{G}^{* * a}$} \\
\hline \multirow[t]{2}{*}{ Parameters } & \multirow[t]{2}{*}{ Gas } & \multirow[t]{2}{*}{ Water } & \multicolumn{2}{|c|}{ Experimental $^{\mathrm{b}}$} \\
\hline & & & Cation $1^{\dagger}$ & Cation 2 \\
\hline \multicolumn{5}{|l|}{ Bond lengths $(\AA)$} \\
\hline $\mathrm{C} 17=\mathrm{O} 4$ & 1217 & 1244 & 1236 & 1244 \\
\hline $\mathrm{C} 16=\mathrm{O} 3$ & 1211 & 1223 & 1219 & 1212 \\
\hline N6-C8 & 1462 & 1470 & 1479 & 1493 \\
\hline N5-C7 & 1457 & 1459 & 1449 & 1450 \\
\hline $\mathrm{C} 10-\mathrm{C} 12$ & 1508 & 1509 & 1481 & 1513 \\
\hline $\mathrm{C} 12=\mathrm{Cl} 1$ & 1338 & 1339 & 1338 & 1330 \\
\hline $\mathrm{C} 16-\mathrm{Cl} 2$ & 1495 & 1489 & 1493 & 1496 \\
\hline C17-N5 & 1376 & 1349 & 1355 & 1335 \\
\hline C9-O1 & 1423 & 1433 & 1420 & 1428 \\
\hline $\mathrm{C} 13-\mathrm{O} 1$ & 1439 & 1454 & 1450 & 1448 \\
\hline $\mathrm{C} 16-\mathrm{O} 2$ & 1351 & 1340 & 1334 & 1340 \\
\hline $\mathrm{C} 21-\mathrm{O} 2$ & 1449 & 1460 & 1471 & 1449 \\
\hline RMSD $^{\dagger}$ & 0.0045 & 0.0032 & & \\
\hline RMSD $^{*}$ & 0.0051 & 0.0030 & & \\
\hline \multicolumn{5}{|l|}{ Bond angles $\left({ }^{\circ}\right)$} \\
\hline C17-N5-C7 & 123.3 & 125.1 & 125.0 & 123.3 \\
\hline N5-C7-C9 & 110.7 & 110.3 & 111.6 & 110.7 \\
\hline C20-C17-O4 & 121.7 & 120.8 & 122.9 & 121.6 \\
\hline C20-C17-N5 & 115.0 & 116.1 & 115.5 & 118.1 \\
\hline N5-C17-O4 & 123.2 & 123.1 & 121.6 & 120.3 \\
\hline $\mathrm{C} 12-\mathrm{C} 16-\mathrm{O} 3$ & 125.4 & 125.2 & 123.5 & 123.9 \\
\hline C9-O1-C13 & 116.8 & 115.7 & 116.4 & 114.6 \\
\hline $\mathrm{C} 16-\mathrm{O} 2-\mathrm{C} 21$ & 116.5 & 117.8 & 113.9 & 115.4 \\
\hline C14-C13-O1 & 110.3 & 109.8 & 110.7 & 105.5 \\
\hline $\mathrm{C} 15-\mathrm{C} 13-\mathrm{O} 1$ & 106.5 & 106.9 & 106.5 & 110.7 \\
\hline C14-C13-C15 & 113.2 & 113.6 & 115.4 & 113.1 \\
\hline N6-C8-C10 & 108.5 & 109.2 & 110.5 & 110.9 \\
\hline N6-C8-C7 & 109.9 & 110.5 & 110.5 & 111.5 \\
\hline $\mathrm{Cl0}-\mathrm{C} 12-\mathrm{C} 11$ & 122.4 & 122.3 & 123.3 & 121.3 \\
\hline $\mathrm{Cl0}-\mathrm{C} 8-\mathrm{C} 7$ & 110.4 & 110.2 & 111.4 & 110.5 \\
\hline C7-C9-C11 & 112.0 & 111.8 & 111.6 & 110.0 \\
\hline C9-C11-C12 & 124.4 & 124.1 & 123.5 & 125.9 \\
\hline RMSD $^{\dagger}$ & $\mathbf{0 . 3 2}$ & $0.35^{\dagger}$ & & \\
\hline RMSD $^{*}$ & $0.53^{+}$ & $0.49^{\ddagger}$ & & \\
\hline \multicolumn{5}{|l|}{ Dihedral angles $\left({ }^{\circ}\right)$} \\
\hline C7-N5-C17-O4 & 9.5 & 0.9 & 3.2 & 1.4 \\
\hline C17-N5-C7-C8 & 124.3 & -114.3 & -126.3 & -102.3 \\
\hline N6-C8-C7-C9 & 178.2 & 176.5 & 174.0 & 167.5 \\
\hline N6-C8-C7-N5 & 54.8 & 53.9 & 49.9 & 44.6 \\
\hline N5-C7-C9-O1 & -68.0 & -68.9 & -66.1 & -67.5 \\
\hline O3-C16-O2-C21 & -0.8 & -0.2 & 4.8 & 0.5 \\
\hline C15-C13-O1-C9 & 153.8 & 152.2 & 159.5 & 75.8 \\
\hline C14-C13- O1-C9 & -83.1 & -84.1 & -74.3 & -161.5 \\
\hline C7-N5-C17-C20 & -171.1 & -179.3 & -175.1 & -178.7 \\
\hline $\mathrm{C} 12-\mathrm{C} 16-\mathrm{O} 2-\mathrm{C} 21$ & 179.0 & 179.2 & -176.9 & -179.2 \\
\hline $\mathrm{C} 16-\mathrm{O} 2-\mathrm{C} 21-\mathrm{C} 22$ & -179.4 & 178.7 & -176.2 & 172.4 \\
\hline RMSD & $\begin{array}{l}\mathbf{3 9 . 6 0}^{\dagger} \\
\mathbf{5 1 . 1 0}\end{array}$ & $\begin{array}{l}\text { 45.74 } \\
\text { 34.09 }\end{array}$ & & \\
\hline
\end{tabular}

${ }^{\mathrm{a}}$ This work

${ }^{\mathrm{b}} \operatorname{Ref}[54]$ 
reactions of Oseltamivir with electrophil and nucleophil potential biological reactive, respectively.

\section{Natural bond orbital, NBO, and atoms in molecules, AIM studies}

To discuss the antiviral property of Oseltamivir, the study of its stability in gas and water are useful and interesting. It related to the presence of $\mathrm{N}-\mathrm{H}, \mathrm{NH}_{2}$, and $\mathrm{C}=\mathrm{O}$ groups containing donor $(\mathrm{N}-\mathrm{H})$ and acceptor $\mathrm{H}$ bonds $(\mathrm{O}$ and $\mathrm{N})$. Thus, intra-molecular interactions can be predicted with the second-order perturbation theory analyses, $E^{2}$; were obtained by NBO results and with the topological parameters; and calculated by using the AIM 2000 program [46-48]. Regarding the donor-acceptor interactions of Oseltamivir in both phases, we observed five $\pi \rightarrow \pi^{*}$, $\sigma \rightarrow \sigma^{*}, n \rightarrow \pi^{*}, n \rightarrow \sigma^{*}$, and $\pi^{*} \rightarrow \pi^{*}$ interactions in the mentioned media, while the $\pi^{*} \rightarrow \sigma^{*}$ and $\sigma^{*} \rightarrow \pi^{*}$ interactions are respectively observed only in gas and aqueous media (see Table S1, see supplementary materials). Nevertheless,
Table 6 Molecular electrostatic potentials (MEP) (a.u.) and bond orders, expressed as Wiberg indexes of antiviral Oseltamivir in two media by using B3LYP/6-311++ $\mathrm{G}^{* *}$ level of theory

\begin{tabular}{llllll}
\hline \multirow{2}{*}{ Atoms } & \multicolumn{2}{l}{ Wiberg Index } & & MEP \\
\cline { 2 - 3 } \cline { 6 - 6 } & Gas & Water & & Gas & Water \\
\hline O1 & 2008 & 1981 & & $-22,366$ & $-22,367$ \\
O2 & 2150 & 2166 & & $-22,325$ & $-22,324$ \\
O3 & 2017 & 1959 & & $-22,389$ & $-22,392$ \\
O4 & 1995 & 1874 & & $-22,414$ & $-22,422$ \\
N5 & 3219 & 3272 & & $-18,367$ & $-18,363$ \\
N6 & 2823 & 2800 & & $-18,414$ & $-18,411$ \\
C7 & 3930 & 3934 & & $-14,728$ & $-14,727$ \\
C8 & 3962 & 3956 & & $-14,730$ & $-14,729$ \\
\hline
\end{tabular}

the $\mathrm{LP}(1) \mathrm{O} 3 \rightarrow \sigma^{*} \mathrm{O} 2-\mathrm{Cl} 6$ interaction observed in gas phase has a value of $136.06 \mathrm{~kJ} / \mathrm{mol}$ which decreases to $125.02 \mathrm{~kJ} / \mathrm{mol}$ in water as solvent, while the value of $L P(1)$ $O 4 \rightarrow \sigma^{*} N 5-C 17$ interaction is $105.84 \mathrm{~kJ} / \mathrm{mol}$ in gas phase
Table 5 Mulliken, MerzKollman, and NPA charges (a.u.) of antiviral Oseltamivir in two media by using B3LYP/6$311++\mathrm{G}^{* *}$ level of theory
Fig. 3 Variations of MK, atomic Mulliken, and NPA charges on $\mathrm{N}, \mathrm{O}$, and $\mathrm{C}$ atoms of Oseltamivir in gas phase by using the B3LYP/6-311+ + G** level

\begin{tabular}{|c|c|c|c|c|c|c|}
\hline \multirow[b]{2}{*}{ Atoms } & \multicolumn{2}{|l|}{ MK } & \multicolumn{2}{|l|}{ Mulliken } & \multicolumn{2}{|l|}{ NPA } \\
\hline & gas & Water & Gas & PCM Ely & gas & Water \\
\hline $\mathrm{O} 1$ & -0.065 & -0.062 & 0.245 & 0.145 & -0.610 & -0.628 \\
\hline $\mathrm{O} 2$ & -0.393 & -0.397 & -0.033 & -0.045 & -0.565 & -0.558 \\
\hline $\mathrm{O} 3$ & -0.072 & -0.074 & -0.221 & -0.316 & -0.607 & -0.655 \\
\hline $\mathrm{O} 4$ & -0.562 & -0.555 & -0.247 & -0.404 & -0.620 & -0.717 \\
\hline N5 & -0.490 & -0.496 & 0.101 & 0.091 & -0.654 & -0.623 \\
\hline N6 & -0.393 & -0.397 & -0.320 & -0.425 & -0.839 & -0.860 \\
\hline $\mathrm{C} 7$ & -0.475 & -0.451 & -0.614 & -0.511 & -0.048 & -0.042 \\
\hline $\mathrm{C} 8$ & 0.652 & 0.654 & 0.367 & 0.226 & -0.014 & -0.018 \\
\hline
\end{tabular}

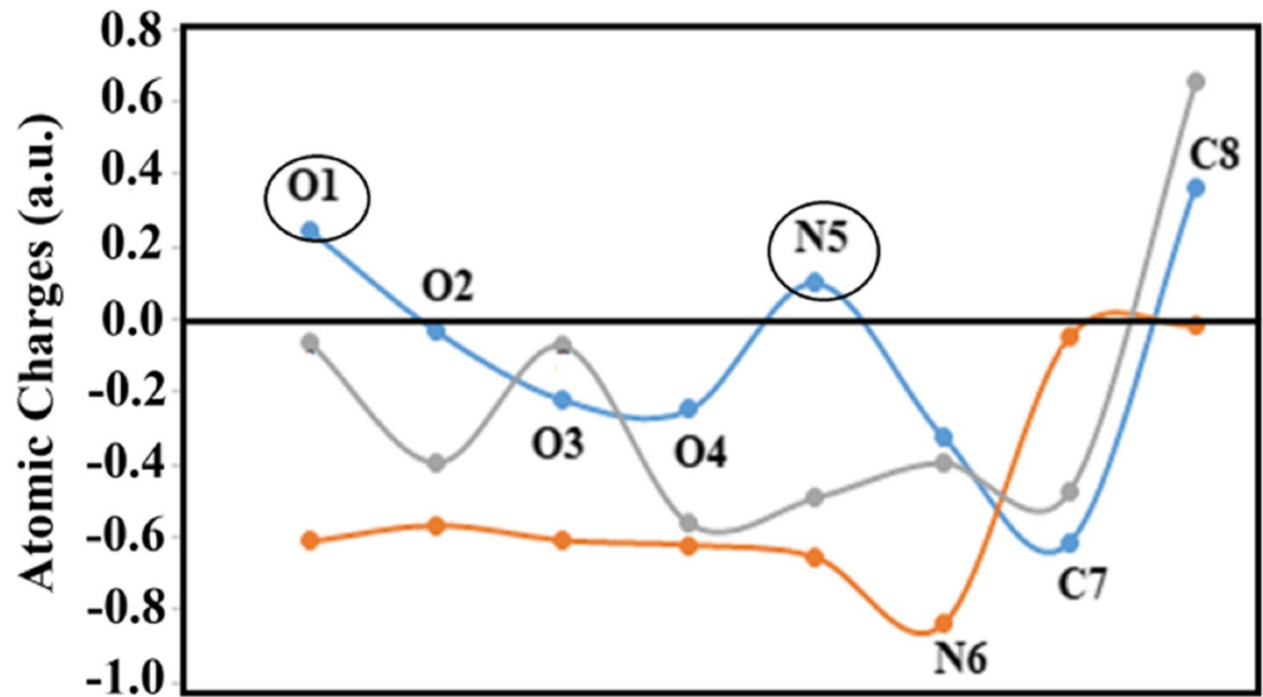

$\rightarrow$ Mulliken $\rightarrow$ NPA $\rightarrow$ MK 
which decreases very much in solution to $88.99 \mathrm{~kJ} / \mathrm{mol}$. On the contrary, the $L P(1) N 5 \rightarrow \sigma^{*} O 4-C 17$ interaction is very weak in gas, $6.10 \mathrm{~kJ} / \mathrm{mol}$, while in solution, it increases considerably to $221.79 \mathrm{~kJ} / \mathrm{mol}$. Finally, it can be seen that the $\sigma^{*} \mathrm{O} 4-\mathrm{Cl7} \rightarrow \pi^{*} \mathrm{O} 4-\mathrm{Cl} 17$ interaction only occurs in solution, while the $\pi^{*} \mathrm{O} 4-\mathrm{Cl7} \rightarrow \sigma^{*} \mathrm{O} 4-\mathrm{Cl} 1$ interaction only occurs in the other phase, gas phase. The total energy favours to Oseltamivir in solution $(1291.97 \mathrm{~kJ} / \mathrm{mol})$ because the value is lower in gas phase $(1282.81 \mathrm{~kJ} / \mathrm{mol})$. Hence, Oseltamivir in water is more stable than that in gas phase.

The AIM results can be predicted the topological properties in the bond critical points (BCPs) and ring critical points (RCPs). Thus, the electron density, $\rho(r)$; the Laplacian values, ${ }^{2} \rho(r)$; the eigenvalues $(\lambda 1, \lambda 2, \lambda 3)$ of the Hessian matrix; and the $|\lambda 1| / \lambda 3$ ratio were calculated for Oseltamivir (Table S2, see supplementary materials). We observed that there are not new bonds or ring critical points formed in the two media. The ionic or highly polar covalent interactions, such as $\mathrm{C}=\mathrm{O}$ bonds, have $\lambda 1 / \lambda 3<1$, while for $\mathrm{N}-\mathrm{H}$ bonds, $\lambda 1 / \lambda 3>1$. On other hand, in all cases, ${ }^{2} \rho(r)>0$ (closed-shell interaction) and the eigenvalues of the Hessian matrix have approximately the same values in both media. The molecular graphs of Oseltamivir in gas and aqueous solution show the absence of new critical points (Figure S3, see supplementary materials).

\section{HOMO-LUMO and chemical quantum global descriptors}

The differences between HOMO, highest occupied molecular orbital, and LUMO lowest unoccupied molecular orbital are known as gap values that used to guess reactivities, as was suggested by Parr and Pearson [56], while the global descriptors can use to predict the behaviours of molecule too [37-42, 50]. In this study, the HOMO, LUMO, energy band gaps and the chemical potential $(\mu)$, electronegativity $(\chi)$, global hardness $(\eta)$, global softness $(S)$, global electrophilicity index $(\omega)$, and global nucleophilicity index $(E)$ descriptors [38-43] for Oseltamivir in different media are shown in Table S3, see supplementary materials, together with the equations to compute them. Parameters reported for antiviral species are also presented in the same table. Analyzing Table S3 shows Oseltamivir has a similar gap value $(5.2817 \mathrm{eV})$ to Cidofovir $(5.2964 \mathrm{eV})$ in gas phase. This result is very important taking into account that Cidofovir is an antiviral agent used against the Ebola disease. However, Chloroquine in the two media is an antiviral most reactive than Oseltamivir. The gap values generally decrease in solution except for the case of Emtricitabine and Oseltamivir, while the values of global $(\omega)$ and $(E)$ for Oseltamivir in water are greater than those in the gas, although the gap value is greater in solution, as observed in Table S3, see supplementary materials, which could suggest higher hydration and low reactivities in the mentioned media. Possibly, the higher solvation energy of Oseltamivir $(-127.37 \mathrm{~kJ} / \mathrm{mol})$ and for Chloroquine $(-55.07 \mathrm{~kJ} / \mathrm{mol}$ and $-59.91 \mathrm{~kJ} / \mathrm{mol}$, for $\mathrm{S}$ and $\mathrm{R}$, respectively) could be supported by the higher values of $\omega$ and $E$ in both medium.

\section{Vibrational study}

There are 144 normal modes for the optimized structure of Oseltamivir in aforementioned media with $C_{1}$ symmetries. In the normal internal coordinate's analysis, the $\mathrm{NH}_{2}$ and $\mathrm{CH}_{3}$ groups were considered with $C_{2 v}$ and $C_{3 v}$ symmetries, respectively. The reported IR spectrum of Oseltamivir phosphate in the solid phase obtained from Ref. [9] is compared in Fig. 5 with the calculated in two media, while the theoretical Raman spectra for Oseltamivir in the mentioned media are compared in Figure S4, see supplementary materials. The hydration of Oseltamivir in aqueous solution causes a change in the wavenumbers and intensities of IR bands in
Fig. 4 Calculated electrostatic potential surfaces on the molecular surfaces of Oseltamivir in gas phase (left) and water solution (right) by using the B3LYP/6-311+ + G** level. Color ranges \pm 0.0463 a.u. Isodensity value of $0.004 a$.u
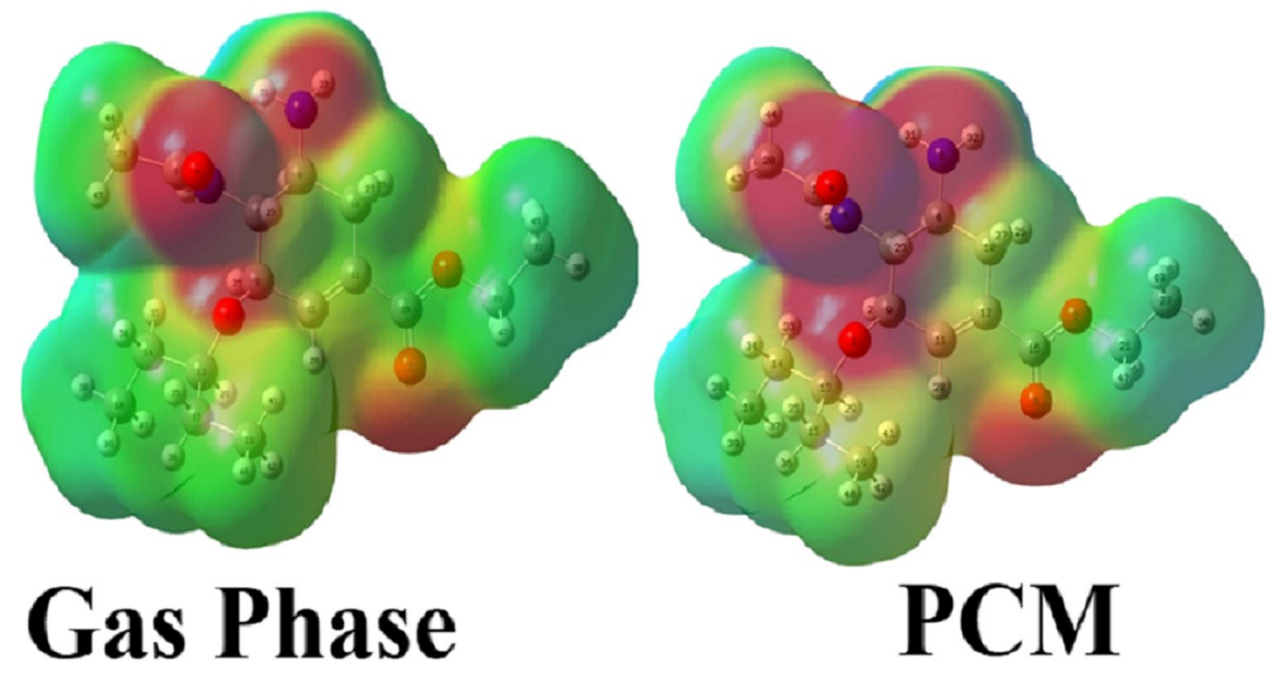


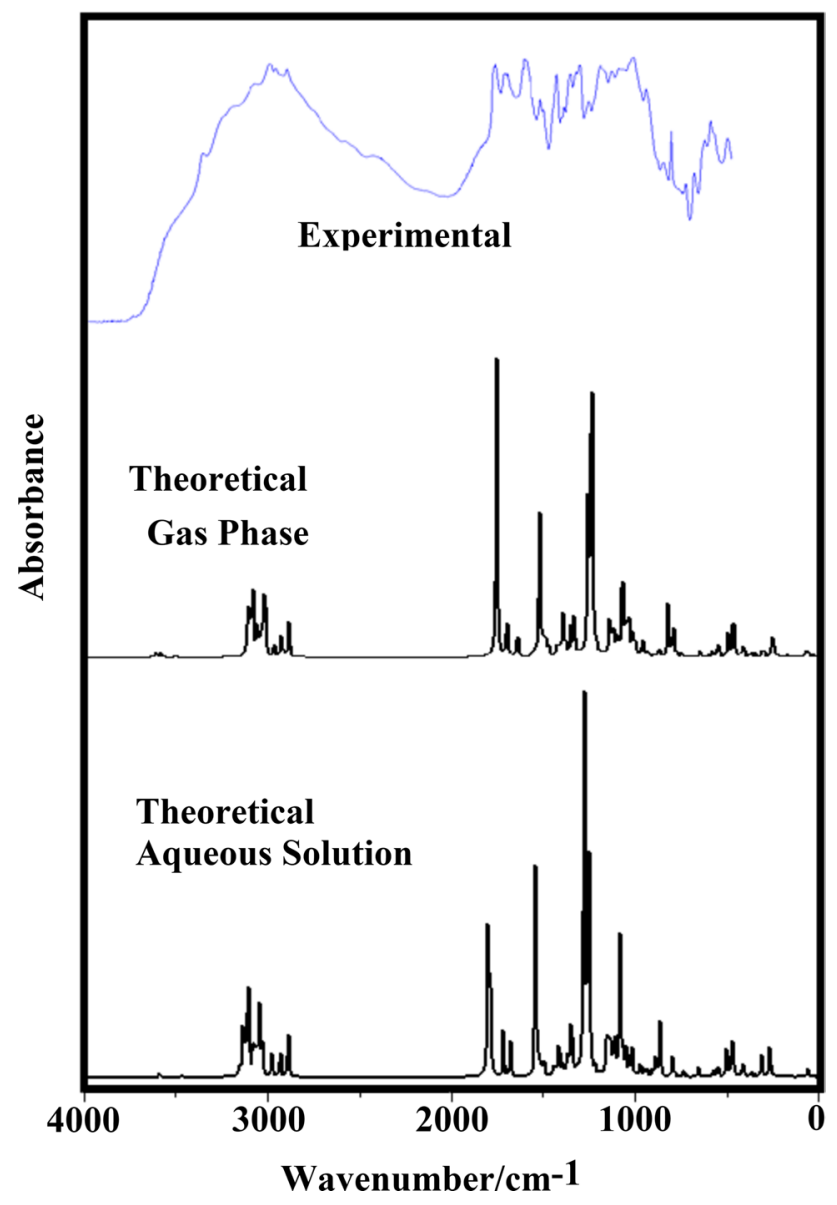

Fig. 5 Comparison of experimental infrared spectra of oseltamivir phosphate in solid phase [9] with the corresponding to oseltamivir in gas phase and aqueous solution by using the hybrid B3LYP/6$311++\mathrm{G}^{* *}$ method

the 4000-2500 and 2000-10 $\mathrm{cm}^{-1}$ regions (see Figure S5, see supplementary materials). Full vibrational assignments for Oseltamivir in both media were done with the SQMFF approach and the Molvib program and, considering the normal internal coordinates and the corresponding harmonic force fields calculated [22, 25]. In this study, the suggested scale factors were used and only potential energy distribution contributions (PED) $>10 \%$ were taken into account $[23$, 24]. Table 7 presents a comparison between the observed wavenumbers with those calculated for Oseltamivir. Some of the most important vibrational band assignments were discussed by regions, see below.

\section{Vibrational band assignments}

$4000-2000 \mathrm{~cm}^{-1}$ region In this region, the $\mathrm{NH}$ and $\mathrm{CH}$ stretching modes are expected [29-32, 37-41]. First, the weak intensity IR band at $3347 \mathrm{~cm}^{-1}$ is attributed to $\mathrm{NH}$ stretching mode; its calculated wavenumber obtained at
3460 and $3440 \mathrm{~cm}^{-1}$ in gas and aqueous solution, respectively. The IR shoulders at $3227 \mathrm{~cm}^{-1}$ and $3172 \mathrm{~cm}^{-1}$ are assigned to the antisymmetric and symmetric stretching modes of $\mathrm{NH}_{2}$, respectively. The calculated $\mathrm{NH}_{2}$ antisymmetric vibrations are obtained by SQM results at $3437 \mathrm{~cm}^{-1}$ in gas and at $3404 \mathrm{~cm}^{-1}$ in solution, while their symmetric movement are calculated at 3361 and $3339 \mathrm{~cm}^{-1}$, respectively. The calculated $\mathrm{CH}_{3}$ and $\mathrm{CH}_{2}$ antisymmetric vibrations are between 2994 and $2924 \mathrm{~cm}^{-1}$, while their symmetric movements are between 2914 and $2894 \mathrm{~cm}^{-1}$. The shoulder IR band at $2993 \mathrm{~cm}^{-1}$ and the very strong intensity IR band at $2977 \mathrm{~cm}^{-1}$ are assigned to $\mathrm{CH}_{3}$ antisymmetric vibration modes. The very strong intensity IR band at $2941 \mathrm{~cm}^{-1}$ is assigned to the $\mathrm{CH}_{2}$ antisymmetric stretching, while the shoulder at $2913 \mathrm{~cm}^{-1}$ is attributed to the symmetric stretching of methyl group. The very intensity IR band at $2877 \mathrm{~cm}^{-1}$ and the broad and strong intensity band at $2567 \mathrm{~cm}^{-1}$ are assigned to the $\mathrm{C}-\mathrm{H}$ stretching modes. Their calculated bands are predicted between 2846 and $2771 \mathrm{~cm}^{-1}$ in gas and 2883 and $2847 \mathrm{~cm}^{-1}$ in aqueous solution.

1800-800 $\mathrm{cm}^{-1}$ region In this region, the $\mathrm{C}=\mathrm{O}$ and $\mathrm{C}=\mathrm{C}$ stretching vibrations are expected [31, 36, 38, 40, 41]. The very strong intensity band at $1715 \mathrm{~cm}^{-1}$ and two strong intensity bands at $1663 \mathrm{~cm}^{-1}$ and $1651 \mathrm{~cm}^{-1}$ are attributed to them. According to SQM results, the $\mathrm{C}=\mathrm{O}$ stretching obtained at $1698 \mathrm{~cm}^{-1}$ and $1697 \mathrm{~cm}^{-1}$ in gas and at $1590 \mathrm{~cm}^{-1}$ and $1573 \mathrm{~cm}^{-1}$ in solution, while the calculated $\mathrm{C}=\mathrm{C}$ stretching mode belonging to the ring is observed at 1637 and $1644 \mathrm{~cm}^{-1}$ in gas and solution, respectively. In addition, the deformation, wagging, and rocking modes of $\mathrm{NH}_{2}, \mathrm{CH}_{3}, \mathrm{CH}_{2}$, and $\mathrm{C}-\mathrm{H}$ groups appear in this region $[36,37,41,59]$. In consequence, the very strong intensity band at $1549 \mathrm{~cm}^{-1}$ is attributed to $\mathrm{NH}_{2}$ deformation mode, $\delta \mathrm{NH}_{2}$, and its calculated values by SQM remarked at 1572 and $1535 \mathrm{~cm}^{-1}$ in gas and solution, respectively. The very strong intensity IR band at $1535 \mathrm{~cm}^{-1}$ is assigned to $\rho \mathrm{H} 30-\mathrm{N} 5$ in gas phase and to $\mathrm{C} 17-\mathrm{N} 5$ stretching in solutions, which are predicted at $1506 \mathrm{~cm}^{-1}$ and $1512 \mathrm{~cm}^{-1}$. The $\mathrm{CH}_{2}$ deformation modes and $\mathrm{CH}_{3}$ antisymmetric deformations, $\delta_{\mathrm{a}} \mathrm{CH}_{3}$, modes are observed between 1453 and $1408 \mathrm{~cm}^{-1}$ in gas and between $1434 \mathrm{~cm}^{-1}$ and $1394 \mathrm{~cm}^{-1}$ in solution. The symmetric deformations of $\mathrm{CH}_{3}, \delta_{\mathrm{s}} \mathrm{CH}_{3}$, are obtained between 1353 and $1337 \mathrm{~cm}^{-1}$ in gas phase and between 1348 and $1338 \mathrm{~cm}^{-1}$ in solution. The very strong IR band at $1243 \mathrm{~cm}^{-1}$ is assigned to rocking mode of $\mathrm{NH}_{2}, \rho \mathrm{NH}_{2}$. In both phases, the calculation wavenumbers of wagging and rocking movements are obtained between 1390/1278 in gas and $1387 / 1276 \mathrm{~cm}^{-1}$ in solution (see Table 7 for their details). The SQM results that obtained the calculated $\rho \mathrm{CH}$ rocking modes were obtained between 1332 and $1235 \mathrm{~cm}^{-1}$ by SQM results. According to calculation results, the strong intensity IR band at $1063 \mathrm{~cm}^{-1}$ is assigned to C-N 
Table 7 Observed and calculated wavenumbers $\left(\mathrm{cm}^{-1}\right)$ and assignments for Oseltamivir in gas phase by using the hybrid B3LYP method

\begin{tabular}{|c|c|c|c|c|c|}
\hline \multicolumn{2}{|c|}{ Experimental } & \multicolumn{4}{|c|}{ B3LYP/6-311+ + G** Method } \\
\hline \multirow[t]{2}{*}{ IR } & \multirow[t]{2}{*}{ Int } & \multicolumn{2}{|l|}{ GAS } & \multicolumn{2}{|l|}{ PCM } \\
\hline & & $\mathrm{SQM}^{\mathrm{c}}$ & Assignments ${ }^{\mathrm{a}}$ & $\mathrm{SQM}^{\mathrm{d}}$ & Assignments $^{\mathrm{a}}$ \\
\hline $3347 w$ & 10.8 & 3460 & vN5-H30 & 3440 & $\nu \mathrm{N} 5-\mathrm{H} 30$ \\
\hline $3227 \mathrm{sh}$ & 4.3 & 3437 & $\nu_{\mathrm{a}} \mathrm{NH}_{2}$ & 3404 & $\nu_{\mathrm{a}} \mathrm{NH}_{2}$ \\
\hline 3172sh & 1.3 & 3361 & $\nu_{\mathrm{s}} \mathrm{NH}_{2}$ & 3339 & $\nu_{\mathrm{s}} \mathrm{NH}_{2}$ \\
\hline 3064 sh & 1.9 & 3045 & レC11-H28 & 3048 & $\nu \mathrm{C} 11-\mathrm{H} 28$ \\
\hline \multirow[t]{4}{*}{ 2993sh } & 8.9 & 2994 & $\nu_{\mathrm{a}} \mathrm{CH}_{3}(\mathrm{C} 20)$ & 3003 & $\nu_{\mathrm{a}} \mathrm{CH}_{3}(\mathrm{C} 20)$ \\
\hline & 36.7 & 2986 & $\nu_{\mathrm{a}} \mathrm{CH}_{3}(\mathrm{C} 22)$ & 2995 & $\nu_{\mathrm{a}} \mathrm{CH}_{2}(\mathrm{C} 21)$ \\
\hline & 31.7 & 2982 & $\nu_{\mathrm{a}} \mathrm{CH}_{3}(\mathrm{C} 19)$ & 2984 & $\nu_{\mathrm{a}} \mathrm{CH}_{3}(\mathrm{C} 20)$ \\
\hline & 13.5 & 2978 & $\nu_{\mathrm{a}} \mathrm{CH}_{3}(\mathrm{C} 20)$ & 2977 & $\nu_{\mathrm{a}} \mathrm{CH}_{3}(\mathrm{C} 22)$ \\
\hline \multirow[t]{7}{*}{2977 vs } & 27.7 & 2974 & $\nu_{\mathrm{a}} \mathrm{CH}_{3}(\mathrm{C} 22)$ & 2972 & $\nu_{\mathrm{a}} \mathrm{CH}_{3}(\mathrm{C} 22)$ \\
\hline & 34.9 & 2966 & $v_{\mathrm{a}} \mathrm{CH}_{3}(\mathrm{C} 18)$ & 2970 & $\nu \mathrm{C} 7-\mathrm{H} 23$ \\
\hline & 7.6 & 2964 & レC7-H23 & 2966 & $v_{\mathrm{a}} \mathrm{CH}_{3}(\mathrm{C} 19)$ \\
\hline & 1.8 & 2960 & $v_{\mathrm{a}} \mathrm{CH}_{2}(\mathrm{C} 21)$ & 2963 & $\nu_{\mathrm{a}} \mathrm{CH}_{3}(\mathrm{C} 18)$ \\
\hline & 63.9 & 2956 & $\nu_{\mathrm{a}} \mathrm{CH}_{3}(\mathrm{C} 18)$ & 2955 & $\nu_{\mathrm{a}} \mathrm{CH}_{3}(\mathrm{C} 18)$ \\
\hline & 28.3 & 2955 & $\nu_{\mathrm{a}} \mathrm{CH}_{3}(\mathrm{C} 19)$ & 2954 & $\nu_{\mathrm{a}} \mathrm{CH}_{3}(\mathrm{C} 19)$ \\
\hline & 16.8 & 2937 & $\nu_{\mathrm{a}} \mathrm{CH}_{2}(\mathrm{C} 10)$ & 2945 & $\nu_{\mathrm{a}} \mathrm{CH}_{2}(\mathrm{C} 10)$ \\
\hline \multirow[t]{4}{*}{ 2941vs } & 20.0 & 2935 & $\nu_{\mathrm{a}} \mathrm{CH}_{2}(\mathrm{C} 15)$ & 2940 & $\nu_{\mathrm{s}} \mathrm{CH}_{2}(\mathrm{C} 21)$ \\
\hline & 16.0 & 2927 & $\nu_{\mathrm{s}} \mathrm{CH}_{2}(\mathrm{C} 21)$ & 2939 & $\nu_{\mathrm{a}} \mathrm{CH}_{2}(\mathrm{C} 15)$ \\
\hline & 15.6 & 2924 & $\nu_{\mathrm{a}} \mathrm{CH}_{2}(\mathrm{C} 14)$ & 2929 & $v_{\mathrm{a}} \mathrm{CH}_{2}(\mathrm{C} 14)$ \\
\hline & 9.9 & 2914 & $\nu_{\mathrm{s}} \mathrm{CH}_{3}(\mathrm{C} 20)$ & 2922 & $\nu_{\mathrm{s}} \mathrm{CH}_{3}(\mathrm{C} 20)$ \\
\hline \multirow[t]{6}{*}{ 2913sh } & 19.5 & 2911 & $\nu_{\mathrm{s}} \mathrm{CH}_{3}(\mathrm{C} 22)$ & 2912 & $\nu_{\mathrm{s}} \mathrm{CH}_{3}(\mathrm{C} 22)$ \\
\hline & 10.8 & 2903 & $\nu_{\mathrm{s}} \mathrm{CH}_{2}(\mathrm{C} 10)$ & 2900 & $\nu_{\mathrm{s}} \mathrm{CH}_{2}(\mathrm{C} 15)$ \\
\hline & 38.0 & 2902 & $\nu_{\mathrm{s}} \mathrm{CH}_{2}(\mathrm{C} 15)$ & 2899 & $\nu_{\mathrm{s}} \mathrm{CH}_{2}(\mathrm{C} 10)$ \\
\hline & 15.6 & 2900 & $\nu_{\mathrm{s}} \mathrm{CH}_{3}(\mathrm{C} 19)$ & 2899 & $\nu_{\mathrm{s}} \mathrm{CH}_{3}(\mathrm{C} 19)$ \\
\hline & 24.8 & 2898 & $\nu_{\mathrm{s}} \mathrm{CH}_{3}(\mathrm{C} 18)$ & 2898 & $\nu_{\mathrm{s}} \mathrm{CH}_{3}(\mathrm{C} 18)$ \\
\hline & 37.2 & 2894 & $\nu_{\mathrm{s}} \mathrm{CH}_{2}(\mathrm{C} 14)$ & 2894 & $\nu_{\mathrm{s}} \mathrm{CH}_{2}(\mathrm{C} 14)$ \\
\hline \multirow[t]{2}{*}{2877 vs } & 25.6 & 2846 & レC13-H29 & 2883 & レC9-H25 \\
\hline & 35.7 & 2805 & レC9-H25 & 2875 & レC13-H29 \\
\hline $2567 \mathrm{~s}, \mathrm{br}$ & 56.1 & 2771 & レC8-H24 & 2847 & レC8-H24 \\
\hline $1715 v s$ & 180.2 & 1698 & $\nu \mathrm{C} 16=\mathrm{O} 3$ & 1644 & $\nu \mathrm{C} 11=\mathrm{C} 12$ \\
\hline $1663 \mathrm{~s}$ & 261.3 & 1697 & $\nu \mathrm{C} 17=\mathrm{O} 4$ & 1590 & $\nu \mathrm{C} 16=\mathrm{O} 3$ \\
\hline $1651 \mathrm{~s}$ & 74.1 & 1637 & $\nu \mathrm{C} 11=\mathrm{C} 12$ & 1573 & $\nu \mathrm{C} 17=\mathrm{O} 4$ \\
\hline $1549 v s$ & 47.8 & 1572 & $\delta \mathrm{NH}_{2}$ & 1535 & $\delta \mathrm{NH}_{2}$ \\
\hline $1535 v s$ & 260.3 & 1506 & $\rho \mathrm{H} 30-\mathrm{N} 5$ & 1512 & レC17-N5 \\
\hline $1464 \mathrm{~m}$ & 5.22 & 1453 & $\delta \mathrm{CH}_{2}(\mathrm{C} 21)$ & 1434 & $\delta \mathrm{CH}_{2}(\mathrm{C} 21)$ \\
\hline \multirow[t]{3}{*}{$1446 w$} & 8.8 & 1446 & $\delta_{\mathrm{a}} \mathrm{CH}_{3}(\mathrm{C} 19)$ & 1430 & $\delta_{a} \mathrm{CH}_{3}(\mathrm{C} 18)$ \\
\hline & 8.6 & 1444 & $\delta_{\mathrm{a}} \mathrm{CH}_{3}(\mathrm{C} 18)$ & 1426 & $\delta_{\mathrm{a}} \mathrm{CH}_{3}(\mathrm{C} 19)$ \\
\hline & 6.3 & 1438 & $\delta_{\mathrm{a}} \mathrm{CH}_{3}(\mathrm{C} 18)$ & 1421 & $\delta_{\mathrm{a}} \mathrm{CH}_{3}(\mathrm{C} 18)$ \\
\hline 1432 sh & 4.2 & 1434 & $\delta_{\mathrm{a}} \mathrm{CH}_{3}(\mathrm{C} 22)$ & 1413 & $\delta_{\mathrm{a}} \mathrm{CH}_{3}(\mathrm{C} 19)$ \\
\hline 1432 sh & 8.5 & 1433 & $\delta_{\mathrm{a}} \mathrm{CH}_{3}(\mathrm{C} 19)$ & 1412 & $\delta_{\mathrm{a}} \mathrm{CH}_{3}(\mathrm{C} 20)$ \\
\hline 1432 sh & 0.6 & 1427 & $\delta_{\mathrm{a}} \mathrm{CH}_{3}(\mathrm{C} 20)$ & 1411 & $\delta_{\mathrm{a}} \mathrm{CH}_{3}(\mathrm{C} 22)$ \\
\hline \multirow[t]{3}{*}{ 1426sh } & 9.6 & 1425 & $\delta \mathrm{CH}_{2}(\mathrm{C} 14)$ & 1408 & $\delta \mathrm{CH}_{2}(\mathrm{C} 14)$ \\
\hline & 7.1 & 1423 & $\delta_{\mathrm{a}} \mathrm{CH}_{3}(\mathrm{C} 22)$ & 1407 & $\delta_{\mathrm{a}} \mathrm{CH}_{3}(\mathrm{C} 22)$ \\
\hline & 6.2 & 1420 & $\delta \mathrm{CH}_{2}(\mathrm{C} 10)$ & 1401 & $\delta \mathrm{CH}_{2}(\mathrm{C} 10)$ \\
\hline 1406sh & 1.6 & 1412 & $\delta \mathrm{CH}_{2}(\mathrm{C} 15)$ & 1398 & $\delta_{\mathrm{a}} \mathrm{CH}_{3}(\mathrm{C} 20)$ \\
\hline 1399sh & 11.3 & 1408 & $\delta_{\mathrm{a}} \mathrm{CH}_{3}(\mathrm{C} 20)$ & 1394 & $\delta \mathrm{CH}_{2}(\mathrm{C} 15)$ \\
\hline 1388 sh & 7.5 & 1390 & $\rho^{\prime} \mathrm{C} 8-\mathrm{H} 24$ & 1387 & $\rho^{\prime} \mathrm{C} 8-\mathrm{H} 24$ \\
\hline $1372 \mathrm{~s}$ & 6.1 & 1378 & $\rho \mathrm{CH}_{2}(\mathrm{C} 21)$ & 1373 & $\rho \mathrm{C} 13-\mathrm{H} 29$ \\
\hline $1372 \mathrm{~s}$ & 5.3 & 1376 & $\rho \mathrm{C} 13-\mathrm{H} 29$ & 1370 & $\rho \mathrm{CH}_{2}(\mathrm{C} 21)$ \\
\hline
\end{tabular}


Table 7 (continued)

\begin{tabular}{|c|c|c|c|c|c|}
\hline \multicolumn{2}{|c|}{ Experimental } & \multicolumn{4}{|c|}{ B3LYP/6-311+ + G** Method } \\
\hline \multirow[t]{2}{*}{ IR } & \multirow[t]{2}{*}{ Int } & \multicolumn{2}{|l|}{ GAS } & \multicolumn{2}{|l|}{ PCM } \\
\hline & & $\mathrm{SQM}^{\mathrm{c}}$ & Assignments $^{\mathrm{a}}$ & $\mathrm{SQM}^{\mathrm{d}}$ & Assignments $^{\mathrm{a}}$ \\
\hline $1366 \mathrm{sh}$ & 2.4 & 1362 & $\mathrm{wagCH}_{2}(\mathrm{C} 10)$ & 1366 & $\rho \mathrm{C} 8-\mathrm{H} 24$ \\
\hline \multirow[t]{3}{*}{ 1360sh } & 7.0 & 1358 & $\rho \mathrm{CH}_{2}(\mathrm{C} 15)$ & 1357 & $\rho \mathrm{CH}_{2}(\mathrm{C} 15) \rho^{\prime} \mathrm{C} 13-\mathrm{H} 29$ \\
\hline & 9.1 & 1353 & $\delta_{\mathrm{s}} \mathrm{CH}_{3}(\mathrm{C} 18)$ & 1348 & $\delta_{\mathrm{s}} \mathrm{CH}_{3}(\mathrm{C} 18)$ \\
\hline & 48.3 & 1349 & $\delta_{\mathrm{s}} \mathrm{CH}_{3}(\mathrm{C} 19)$ & 1346 & $\delta_{\mathrm{s}} \mathrm{CH}_{3}(\mathrm{C} 22)$ \\
\hline 1342 sh & 2.6 & 1347 & $\delta_{\mathrm{s}} \mathrm{CH}_{3}(\mathrm{C} 22)$ & 1345 & $\delta_{\mathrm{s}} \mathrm{CH}_{3}(\mathrm{C} 22) \rho \mathrm{C} 7-\mathrm{H} 23$ \\
\hline 1342 sh & 6.5 & 1345 & $\rho C 9-\mathrm{H} 25 \beta \mathrm{C} 11-\mathrm{H} 28$ & 1340 & $\nu \mathrm{C} 10-\mathrm{C} 12$ \\
\hline $1330 w$ & 14.5 & 1337 & $\delta_{\mathrm{s}} \mathrm{CH}_{3}(\mathrm{C} 20)$ & 1338 & $\delta_{\mathrm{s}} \mathrm{CH}_{3}(\mathrm{C} 19)$ \\
\hline 1330w & 1.1 & 1332 & $\rho \mathrm{C} 8-\mathrm{H} 24 \rho \mathrm{C} 7-\mathrm{H} 23$ & 1331 & $\delta_{\mathrm{s}} \mathrm{CH}_{3}(\mathrm{C} 20)$ \\
\hline 1314sh & 35.2 & 1321 & $\rho C 9-\mathrm{H} 25$ & 1320 & $\rho \mathrm{C} 9-\mathrm{H} 25 \rho \mathrm{C} 7-\mathrm{H} 23$ \\
\hline 1310sh & 7.9 & 1312 & $\operatorname{wagCH}_{2}(\mathrm{C} 14)$ & 1309 & $\operatorname{wagCH}_{2}(\mathrm{C} 14)$ \\
\hline $1295 \mathrm{~s}$ & 55.5 & 1302 & $\rho \mathrm{CH}_{2}(\mathrm{C} 14)$ & 1305 & $\rho \mathrm{CH}_{2}(\mathrm{C} 14)$ \\
\hline $1285 \mathrm{sh}$ & 6.3 & 1294 & $\rho^{\prime} \mathrm{C} 9-\mathrm{H} 25$ & 1297 & $\rho^{\prime} \mathrm{C} 9-\mathrm{H} 25$ \\
\hline $1268 \mathrm{sh}$ & 2.2 & 1287 & wagCH$_{2}(\mathrm{C} 15)$ & 1281 & $\operatorname{wagCH}_{2}(\mathrm{C} 15)$ \\
\hline $1261 \mathrm{~s}$ & 2.5 & 1278 & $\operatorname{wagCH}_{2}(\mathrm{C} 21)$ & 1276 & wagCH$_{2}(\mathrm{C} 21)$ \\
\hline $1253 \mathrm{sh}$ & 0.9 & 1274 & $\beta \mathrm{C} 11-\mathrm{H} 28$ & 1275 & $\beta \mathrm{C} 11-\mathrm{H} 28 \mathrm{wagCH}_{2}(\mathrm{C} 10)$ \\
\hline $1243 v s$ & 4.1 & 1245 & $\rho^{\prime} \mathrm{C} 7-\mathrm{H} 23$ & 1258 & $\nu \mathrm{C} 17-\mathrm{N} 5 \rho \mathrm{N} 5-\mathrm{H} 30$ \\
\hline $1243 v s$ & 9.8 & 1237 & $\rho^{\prime} \mathrm{C} 13-\mathrm{H} 29$ & 1241 & $\rho^{\prime} \mathrm{C} 7-\mathrm{H} 23$ \\
\hline $1243 v s$ & 271.8 & 1233 & $\rho \mathrm{NH}_{2}$ & 1236 & $\rho \mathrm{NH}_{2}$ \\
\hline $1191 \mathrm{~m}$ & 140.1 & 1215 & レC17-N5 & 1235 & $\rho^{\prime} \mathrm{C} 7-\mathrm{H} 23 \rho^{\prime} \mathrm{C} 13-\mathrm{H} 29$ \\
\hline $1191 \mathrm{~m}$ & 473.9 & 1207 & $\nu \mathrm{C} 16-\mathrm{O} 2 \nu \mathrm{C} 12-\mathrm{C} 16$ & 1197 & $\rho \mathrm{CH}_{2}(\mathrm{C} 10) \nu \mathrm{C} 12-\mathrm{C} 16$ \\
\hline 1181sh & 14.2 & 1189 & $\rho \mathrm{CH}_{2}(\mathrm{C} 10)$ & 1182 & $\nu \mathrm{C} 16-\mathrm{O} 2$ \\
\hline 1141 sh & 1.5 & 1138 & $\rho^{\prime} \mathrm{CH}_{3}(\mathrm{C} 19)$ & 1137 & $\rho^{\prime} \mathrm{CH}_{3}(\mathrm{C} 19)$ \\
\hline $1125 v s$ & 3.5 & 1118 & レC7-C9 & 1119 & レC7-C9 \\
\hline \multirow[t]{3}{*}{1113 sh } & 11.1 & 1108 & レC13-C14 & 1107 & レC13-C14 \\
\hline & 49.5 & 1105 & $\rho \mathrm{CH}_{3}(\mathrm{C} 22)$ & 1103 & $\rho \mathrm{CH}_{3}(\mathrm{C} 22)$ \\
\hline & 15.8 & 1103 & $\rho^{\prime} \mathrm{CH}_{3}(\mathrm{C} 18) \nu \mathrm{C} 13-\mathrm{C} 14$ & 1098 & $\beta \mathrm{R}_{1}(\mathrm{~A} 1)$ \\
\hline 1095sh & 17.1 & 1100 & $\rho^{\prime} \mathrm{CH}_{3}(\mathrm{C} 22)$ & 1095 & $\rho^{\prime} \mathrm{CH}_{3}(\mathrm{C} 22)$ \\
\hline 1077sh & 7.3 & 1090 & $\rho \mathrm{CH}_{3}(\mathrm{C} 19)$ & 1084 & $\rho \mathrm{CH}_{3}(\mathrm{C} 19)$ \\
\hline $1063 \mathrm{~s}$ & 36.3 & 1080 & $\nu \mathrm{C} 7-\mathrm{N} 5$ レC7-C8 $\nu \mathrm{C} 8-\mathrm{N} 6$ & 1080 & 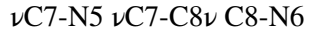 \\
\hline 1053sh & 43.3 & 1058 & レC9-O1 & 1052 & $\tau \mathrm{R}_{1}(\mathrm{~A} 1)$ \\
\hline \multirow[t]{2}{*}{$1024 \mathrm{~s}$} & 180.4 & 1032 & レC9-O1 レC13-O1 & 1034 & $\rho \mathrm{CH}_{3}(\mathrm{C} 20)$ \\
\hline & 36.5 & 1025 & $\rho \mathrm{CH}_{3}(\mathrm{C} 20)$ & 1024 & 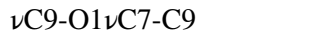 \\
\hline $1024 \mathrm{~s}$ & 3.6 & 1023 & レC9-C11 & 1022 & レC9-C11 \\
\hline $1024 \mathrm{~s}$ & 24.8 & 1011 & $\nu \mathrm{C} 14-\mathrm{C} 18 \nu \mathrm{C} 15-\mathrm{C} 19$ & 1012 & $\nu \mathrm{C} 14-\mathrm{C} 18 \nu \mathrm{C} 13-\mathrm{C} 15$ \\
\hline $990 \mathrm{~s}$ & 36.3 & 1005 & 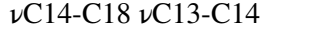 & 1003 & 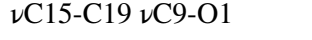 \\
\hline $990 \mathrm{~s}$ & 16.6 & 998 & レC15-C19 & 999 & $\nu \mathrm{C} 15-\mathrm{C} 19$ \\
\hline \multirow[t]{2}{*}{$990 \mathrm{~s}$} & 14.3 & 989 & レC21-C22 & 989 & $\nu \mathrm{C} 21-\mathrm{C} 22$ レC21-O2 \\
\hline & 14.8 & 987 & $\rho \mathrm{CH}_{3}(\mathrm{C} 18)$ & 986 & $\rho \mathrm{CH}_{3}(\mathrm{C} 18)$ \\
\hline $972 \mathrm{~s}$ & 34.7 & 976 & レC8-C10 & 978 & $\nu \mathrm{C} 21-\mathrm{C} 22$ \\
\hline $960 \mathrm{sh}$ & 5.9 & 961 & $\rho^{\prime} \mathrm{CH}_{3}(\mathrm{C} 20)$ & 968 & レC9-O1 レC8-C10 \\
\hline 944vs & 30.7 & 936 & $\gamma \mathrm{C} 11-\mathrm{H} 28$ & 937 & $\gamma \mathrm{C} 11-\mathrm{H} 28 \nu \mathrm{C} 17-\mathrm{C} 20$ \\
\hline $912 \mathrm{sh}$ & 5.5 & 910 & レC17-C20 & 919 & $\gamma \mathrm{C} 11-\mathrm{H} 28$ \\
\hline $894 \mathrm{sh}$ & 1.8 & 907 & $\gamma \mathrm{C} 11-\mathrm{H} 28$ & 909 & $\rho^{\prime} \mathrm{CH}_{3}(\mathrm{C} 18)$ \\
\hline 880sh & 7.0 & 901 & $\nu \mathrm{C} 15-\mathrm{C} 19 \rho^{\prime} \mathrm{CH}_{3}(\mathrm{C} 18)$ & 898 & レC13-O1 \\
\hline $870 \mathrm{~m}$ & 5.8 & 876 & ఒC10-C12 & 888 & wagNH$_{2}$ \\
\hline 850sh & 1.8 & 853 & レC21-O2 & 857 & wagNH 2 \\
\hline $842 \mathrm{sh}$ & 4.5 & 846 & $\rho^{\prime} \mathrm{CH}_{3}(\mathrm{C} 18)$ & 848 & $\nu \mathrm{C} 21-\mathrm{O} 2$ \\
\hline $835 \mathrm{sh}$ & 6.7 & 835 & $\tau \mathrm{wCH}(\mathrm{C} 10)$ & 847 & $\tau \mathrm{wCH}_{2}(\mathrm{C} 10)$ \\
\hline
\end{tabular}


Table 7 (continued)

\begin{tabular}{|c|c|c|c|c|c|}
\hline \multicolumn{2}{|c|}{ Experimental } & \multicolumn{4}{|c|}{ B3LYP/6-311+ + G** Method } \\
\hline \multirow[t]{2}{*}{ IR } & \multirow[t]{2}{*}{ Int } & \multicolumn{2}{|l|}{ GAS } & \multicolumn{2}{|l|}{ PCM } \\
\hline & & $\mathrm{SQM}^{\mathrm{c}}$ & Assignments $^{\mathrm{a}}$ & $\mathrm{SQM}^{\mathrm{d}}$ & Assignments $^{\mathrm{a}}$ \\
\hline $773 w$ & 73.5 & 802 & wagNH$_{2}$ & 836 & $\tau \mathrm{wCH} \mathrm{CH}_{2}(\mathrm{C} 10)$ \\
\hline $773 w$ & 1.8 & 785 & $\beta \mathrm{R}_{1}(\mathrm{~A} 1)$ & 785 & wagC $16=\mathrm{O} 2$ \\
\hline $729 \mathrm{~s}$ & 38.3 & 759 & $\tau \mathrm{wCH} \mathrm{CH}_{2}(\mathrm{C} 21)$ & 769 & $\tau \mathrm{wCH} \mathrm{H}_{2}(\mathrm{C} 21)$ \\
\hline $729 \mathrm{~s}$ & 6.5 & 733 & wagC $16=\mathrm{O} 2$ & 733 & wagC16 $=\mathrm{O} 2 \tau \mathrm{wCH}_{2}(\mathrm{C} 10)$ \\
\hline $721 \mathrm{sh}$ & 0.4 & 717 & $\tau \mathrm{wCH}_{2}(\mathrm{C} 15)$ & 719 & $\tau \mathrm{wCH}(\mathrm{C} 14)$ \\
\hline $650 w$ & 9.5 & 710 & $\tau \mathrm{wCH}_{2}(\mathrm{C} 14) \nu \mathrm{C} 13-\mathrm{C} 15$ & 708 & $\tau \mathrm{wCH}{ }_{2}(\mathrm{C} 15)$ \\
\hline 639sh & 9.2 & 638 & $\nu \mathrm{C} 17-\mathrm{C} 20$ & 640 & wagN5-C17 \\
\hline $602 w$ & 0.5 & 618 & wagN5-C17 & 637 & wagN5-C17 \\
\hline $588 \mathrm{sh}$ & 2.1 & 586 & 8C7C8N6 & 588 & $\delta \mathrm{C7C8N6}$ \\
\hline 572 sh & 9.1 & 571 & $\rho \mathrm{N} 5-\mathrm{C} 17$ & 573 & $\rho \mathrm{N} 5-\mathrm{C} 17$ \\
\hline $540 \mathrm{~m}$ & 13.4 & 545 & $\delta \mathrm{C} 10 \mathrm{C} 8 \mathrm{~N} 6$ & 550 & $\delta \mathrm{C} 10 \mathrm{C} 8 \mathrm{~N} 6$ \\
\hline $540 \mathrm{~m}$ & 5.0 & 535 & $\delta \mathrm{C} 15 \mathrm{C} 13 \mathrm{O} 1 \beta \mathrm{R}_{2}(\mathrm{~A} 1)$ & 542 & $\delta \mathrm{C} 15 \mathrm{C} 13 \mathrm{O} 1$ \\
\hline $509 \mathrm{~m}$ & 32.4 & 494 & $\beta \mathrm{R}_{3}(\mathrm{~A} 1)$ & 509 & wagN5-H30 \\
\hline $477 \mathrm{sh}$ & 41.4 & 464 & wagN5-H30 & 484 & $\beta \mathrm{R}_{3}(\mathrm{~A} 1) \delta \mathrm{N} 5 \mathrm{C} 17 \mathrm{C} 20$ \\
\hline $455 \mathrm{sh}$ & 32.6 & 457 & бC14C13O1 & 462 & 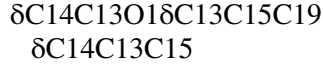 \\
\hline $432 \mathrm{sh}$ & 4.8 & 444 & 8C7C8N6 & 445 & $\delta \mathrm{C} 13 \mathrm{O} 1 \mathrm{C} 9$ \\
\hline $425 \mathrm{sh}$ & 4.6 & 416 & $\delta \mathrm{O} 2 \mathrm{C} 16 \mathrm{C} 12$ & 424 & $\delta \mathrm{O} 2 \mathrm{C} 21 \mathrm{C} 22 \mathrm{OO} 2 \mathrm{C} 16 \mathrm{C} 12$ \\
\hline $413 \mathrm{~m}$ & 3.9 & 408 & 8N5C17C20 & 414 & $\beta \mathrm{R}_{2}(\mathrm{~A} 1)$ \\
\hline \multirow[t]{29}{*}{$397 \mathrm{sh}$} & 14.1 & 405 & $\gamma \mathrm{C} 12-\mathrm{C} 16$ & 403 & $\gamma \mathrm{C} 12-\mathrm{C} 16 \tau \mathrm{R}_{1}(\mathrm{~A} 1)$ \\
\hline & 1.4 & 375 & $\delta \mathrm{O} 2 \mathrm{C} 21 \mathrm{C} 22$ & 378 & 8C8C7N5 \\
\hline & 7.1 & 361 & $\rho \mathrm{C} 16=\mathrm{O} 2$ & 361 & $\gamma \mathrm{C} 12-\mathrm{C} 16 \rho \mathrm{C} 16=\mathrm{O} 2$ \\
\hline & 5.0 & 337 & $\delta \mathrm{C} 9 \mathrm{C} 7 \mathrm{~N} 5$ & 337 & $\delta \mathrm{C} 9 \mathrm{C} 7 \mathrm{~N} 5$ \\
\hline & 0.9 & 303 & $\delta C 13 C 15 C 19$ & 310 & $\delta \mathrm{C} 13 \mathrm{C} 15 \mathrm{C} 19 \tau \mathrm{C} 17-\mathrm{N} 5$ \\
\hline & 13.7 & 300 & 8C7C8N6 & 308 & $\delta \mathrm{C} 7 \mathrm{C} 8 \mathrm{~N} 6$ \\
\hline & 1.5 & 254 & 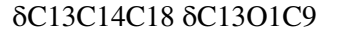 & 260 & 8C13C14C18 \\
\hline & 26.6 & 249 & $\delta \mathrm{C} 21 \mathrm{O} 2 \mathrm{C} 16 \beta \mathrm{C} 12-\mathrm{C} 16$ & 254 & $\delta \mathrm{C} 21 \mathrm{O} 2 \mathrm{C} 16 \beta \mathrm{C} 12-\mathrm{C} 16$ \\
\hline & 4.8 & 233 & $\tau_{\mathrm{w}} \mathrm{CH}_{3}(\mathrm{C} 22)$ & 246 & $\tau_{\mathrm{w}} \mathrm{CH}_{3}(\mathrm{C} 22)$ \\
\hline & 12.3 & 233 & $\tau \mathrm{wNH}_{2} \delta \mathrm{N} 5 \mathrm{C} 17 \mathrm{C} 20$ & 237 & $\tau \mathrm{wNH}_{2}$ \\
\hline & 1.7 & 222 & $\tau \mathrm{wNH}_{2} \tau_{\mathrm{w}} \mathrm{CH}_{3}(\mathrm{C} 18)$ & 235 & $\tau_{\mathrm{w}} \mathrm{CH}_{3}(\mathrm{C} 18) \beta \mathrm{R}_{3}(\mathrm{~A} 1)$ \\
\hline & 2.2 & 208 & $\tau \mathrm{wNH}_{2}$ & 222 & $\tau_{\mathrm{w}} \mathrm{CH}_{3}(\mathrm{C} 18)$ \\
\hline & 0.8 & 196 & $\tau_{\mathrm{w}} \mathrm{CH}_{3}(\mathrm{C} 19)$ & 209 & $\tau_{\mathrm{w}} \mathrm{CH}_{3}(\mathrm{C} 19)$ \\
\hline & 1.5 & 176 & $\tau_{\mathrm{w}} \mathrm{CH}_{3}(\mathrm{C} 18) \delta \mathrm{C} 14 \mathrm{C} 13 \mathrm{C} 15$ & 187 & $\tau_{\mathrm{w}} \mathrm{CH}_{3}(\mathrm{C} 18) \delta \mathrm{C} 14 \mathrm{C} 13 \mathrm{C} 15$ \\
\hline & 1.8 & 169 & $8 \mathrm{C} 7 \mathrm{~N} 5 \mathrm{C} 17$ & 175 & $\rho \mathrm{N} 5-\mathrm{H} 30$ \\
\hline & 2.5 & 145 & $\tau \mathrm{R}_{1}(\mathrm{~A} 1)$ & 152 & $\tau \mathrm{C} 14-\mathrm{C} 13 \tau_{\mathrm{w}} \mathrm{CH}_{3}(\mathrm{C} 20)$ \\
\hline & 0.2 & 131 & $\tau \mathrm{R}_{2}(\mathrm{~A} 1)$ & 145 & $\tau_{\mathrm{w}} \mathrm{CH}_{3}(\mathrm{C} 20)$ \\
\hline & 1.2 & 108 & ¿C8C7N58C10C8N6 & 139 & $\tau \mathrm{R}_{2}(\mathrm{~A} 1)$ \\
\hline & 0.0 & 94 & $\tau \mathrm{O} 2-\mathrm{C} 16$ & 120 & $\tau \mathrm{C} 14-\mathrm{C} 13$ \\
\hline & 0.3 & 90 & $\tau \mathrm{C} 14-\mathrm{C} 13$ & 110 & $\tau \mathrm{C} 21-\mathrm{O} 2$ \\
\hline & 0.2 & 86 & $\tau \mathrm{C} 15-\mathrm{C} 13$ & 102 & $\tau \mathrm{C} 21-\mathrm{O} 2$ \\
\hline & 0.4 & 70 & $\tau_{\mathrm{w}} \mathrm{CH}_{3}(\mathrm{C} 20)$ & 91 & $\tau \mathrm{O} 2-\mathrm{C} 16$ \\
\hline & 0.8 & 68 & $\tau \mathrm{C} 21-\mathrm{O} 2$ & 86 & $\delta \mathrm{C} 10 \mathrm{C} 8 \mathrm{~N} 6$ \\
\hline & 6.2 & 60 & $\tau \mathrm{C} 17-\mathrm{N} 5 \tau \mathrm{C} 14-\mathrm{C} 13$ & 72 & $\tau \mathrm{C} 15-\mathrm{C} 13$ \\
\hline & 6.2 & 55 & $\tau \mathrm{C} 17-\mathrm{N} 5$ & 64 & $\tau \mathrm{C} 17-\mathrm{N} 5$ \\
\hline & 0.8 & 45 & $\tau \mathrm{N} 5-\mathrm{C} 7$ & 54 & $\tau \mathrm{N} 5-\mathrm{C} 7$ \\
\hline & 0.6 & 36 & $\tau \mathrm{C} 13-\mathrm{O} 1$ & 45 & $\tau \mathrm{wC} 16-\mathrm{C} 12 \tau \mathrm{N} 5-\mathrm{C} 7$ \\
\hline & 1.8 & 29 & $\tau \mathrm{R}_{3}(\mathrm{~A} 1)$ & 32 & $\tau \mathrm{C} 13-\mathrm{O} 1 \tau \mathrm{R}_{3}(\mathrm{~A} 1)$ \\
\hline & 1.8 & 24 & $\tau \mathrm{wC} 16-\mathrm{C} 12$ & 28 & $\tau \mathrm{wC} 16-\mathrm{C} 12$ \\
\hline
\end{tabular}


Table 7 (continued)

\begin{tabular}{|c|c|c|c|c|c|}
\hline \multicolumn{2}{|c|}{ Experimental } & \multicolumn{4}{|c|}{ B3LYP/6-311+ + G** Method } \\
\hline \multirow[t]{3}{*}{ IR } & \multirow[t]{2}{*}{ Int } & \multicolumn{2}{|l|}{ GAS } & \multicolumn{2}{|l|}{$\mathrm{PCM}$} \\
\hline & & $\overline{\mathrm{SQM}^{\mathrm{c}}}$ & $\overline{\text { Assignments }}{ }^{\mathrm{a}}$ & $\overline{\mathrm{SQM}^{\mathrm{d}}}$ & Assignments $^{\mathrm{a}}$ \\
\hline & 0.0 & 19 & $\tau \mathrm{O} 1-\mathrm{C} 9$ & 23 & $\tau \mathrm{O} 1-\mathrm{C} 9$ \\
\hline
\end{tabular}

Abbreviations: $\nu$ stretching, $\beta$ deformation in the plane, $\gamma$ deformation out of plane, wag wagging, $\tau$ torsion, $\rho$ rocking, $T w$ twisting, $\delta$ deformation, $a$ antisymmetric, $s$ symmetric

${ }^{\mathrm{a}}$ This work

${ }^{\mathrm{b}}$ From scaled quantum mechanics force field with B3LYP/6-311+ + G** method

${ }^{c}$ From scaled quantum mechanics force field with B3LYP/6-31G* method

${ }^{\mathrm{d}}$ From B3LYP/6-31G* method,

stretching; its calculated band was obtained at $1080 \mathrm{~cm}^{-1}$ in both phases. In relation to $\mathrm{C}-\mathrm{O}$ stretching, the $\mathrm{C} 16-\mathrm{O} 2$ stretching wavenumber is obtained at higher wavenumbers than of other ones, perhaps because the $\mathrm{C} 16$ belongs to the $\mathrm{C} 16=\mathrm{O} 3$ group. This band is obtained at $1207 \mathrm{~cm}^{-1}$ in the gas and at $1182 \mathrm{~cm}^{-1}$ in water, while for the other C-O bonds are observed at 1058,1032 , and $853 \mathrm{~cm}^{-1}$ in gas and 1024 , 898 , and $848 \mathrm{~cm}^{-1}$ in solution. However, the experimental IR band at $1191 \mathrm{~cm}^{-1}$ assigned to C16-O2 stretching and the signals at 1053, 1024, 880,850, and $842 \mathrm{~cm}^{-1}$ are attributed to other $\mathrm{C}-\mathrm{O}$ stretching modes (see Table 7).

Skeletal modes The very intense IR signal at $1125 \mathrm{~cm}^{-1}$ is assigned to C7-C9 stretching, which its calculated wavenumbers in gas and water is 1118 and $1119 \mathrm{~cm}^{-1}$, respectively. The strong intensity IR band at $1024 \mathrm{~cm}^{-1}$ was assigned to

Table 8 Scaled internal force constants for Oseltamivir in gas and water phases by using the B3LYP/6-311++ $\mathrm{G}^{* *}$ method

\begin{tabular}{lll}
\hline Force constants & \multicolumn{2}{l}{ Oseltamivir } \\
\cline { 2 - 3 } & Gas & PCM \\
\hline$f(\nu N-H)$ & 6.64 & 6.56 \\
$f\left(\nu \mathrm{NH}_{2}\right)$ & 6.42 & 6.32 \\
$f\left(\nu \mathrm{CH}_{3}\right)$ & 4.80 & 4.80 \\
$f\left(\nu \mathrm{CH}_{2}\right)_{\text {ring }}$ & 4.71 & 4.71 \\
$\left.f(\nu \mathrm{CH})_{2}\right)$ & 4.72 & 4.75 \\
$f(\nu \mathrm{CH})_{\text {ring }}$ & 4.64 & 4.76 \\
$f(\nu \mathrm{CH})$ & 4.48 & 4.58 \\
$f(\nu \mathrm{C}=\mathrm{O})$ & 11.48 & 9.87 \\
$f(\nu \mathrm{C}=\mathrm{C})$ & 8.59 & 8.49 \\
$f(\nu \mathrm{C}-\mathrm{O})$ & 4.62 & 4.39 \\
$f(\nu \mathrm{N}-\mathrm{C})$ & 5.04 & 5.28 \\
$\left.f(\delta \mathrm{NH})_{2}\right)$ & 0.84 & 0.83 \\
$f\left(\delta \mathrm{CH} \mathrm{H}_{2}\right)$ & 0.75 & 0.73 \\
$f\left(\delta \mathrm{CH} \mathrm{H}_{3}\right)$ & 0.53 & 0.52 \\
$f \beta_{R}$ & 0.21 & 0.21 \\
\hline
\end{tabular}

Units are mdyn $\AA^{-1}$ for stretching and mdyn $\AA \mathrm{rad}^{-2}$ for angle deformations

${ }^{\mathrm{a}}$ This work
C9-C11 stretching, as was predicted by the calculations at $1023 \mathrm{~cm}^{-1}$ in gas and at $1022 \mathrm{~cm}^{-1}$ in water. According to calculated results, other $\mathrm{C}-\mathrm{C}$ stretching modes are predicted in different positions; thus, the strong and medium intensity IR bands at 972 and $870 \mathrm{~cm}^{-1}$ are assigned to these modes, respectively, because the calculations predict these movements at 976 and $876 \mathrm{~cm}^{-1}$ in gas phase, while in solution, these modes appear coupling, as can be seen in Table 7 . Here, the deformations and torsions rings are predicted with strong coupling among them from $1100 \mathrm{~cm}^{-1}$ towards the lower wavenumbers region, as observed in Table 7.

\section{Force constants}

For Oseltamivir in two studied media, the scaled force constants were obtained at above level of theory with the harmonic force fields calculated with the SQMFF methodology [22-24] and Molvib program [25]. These harmonic force constants for Oseltamivir in both media are presented in Table 8. According to this Table, the $f(\nu C=O)$ decreases considerably in solution. This can be justified due to the increased distance of this bond in aqueous solution. Also, the $f(\nu \mathrm{N}-\mathrm{H})$ and $f\left(\nu \mathrm{NH}_{2}\right)$ decreases slightly in solution in comparison with value in gas phase, while the $f(\nu N-C)$ increases. Finally, the other force constants present approximately the same values, while the deformation force constants unchanged in both media. Table 9 shows a comparison of the some values of force constants for Oseltamivir with reported for compounds containing similar groups. This table shows, for all cases, the $f(\nu C=O)$ in gas phase are similar, but in solution, these values decrease irregularly due to the solvation of these groups, while for the other force constants, similar values are observed. 
Table 9 Scaled internal force constants for Oseltamivir in gas and water phases compared with reported for others antivirals by using the B3LYP/6-311+ + G** method

\begin{tabular}{|c|c|c|c|c|c|c|c|c|c|c|}
\hline \multirow[t]{2}{*}{ Force constants } & \multicolumn{2}{|c|}{ Oseltamivir $^{\mathrm{a}}$} & \multicolumn{2}{|c|}{ Rivabirin $(\mathrm{C} 5)^{\mathrm{b}}$} & \multicolumn{2}{|c|}{ Emtricitabine $(\mathrm{C} 6)^{\mathrm{c}}$} & \multicolumn{2}{|c|}{ Zalzitabine $(\mathrm{C} 2)^{\mathrm{d}}$} & \multicolumn{2}{|c|}{ Thymidine $(\mathrm{C} 3)^{\mathrm{e}}$} \\
\hline & Gas & PCM & Gas & PCM & Gas & PCM & Gas & PCM & Gas & PCM \\
\hline$f(\nu N-H)$ & 6.64 & 6.56 & - & - & - & - & - & - & 6.62 & 6.49 \\
\hline$f\left(\nu \mathrm{NH}_{2}\right)$ & 6.42 & 6.32 & 6.83 & 6.72 & 6.88 & 6.80 & 6.82 & 6.74 & - & - \\
\hline$f(\nu C=O)$ & 11.48 & 9.87 & 11.88 & 10.41 & 11.22 & 9.81 & 11.45 & 9.99 & 11.63 & 10.50 \\
\hline$f(\nu C=C)$ & 8.59 & 8.49 & - & - & 8.07 & 8.14 & 7.97 & 8.07 & 8.17 & 8.09 \\
\hline$f(\nu C-O)$ & 4.62 & 4.39 & 4.67 & 4.96 & 4.54 & 4.97 & 4.47 & 4.27 & 4.48 & 4.26 \\
\hline$f(\nu N-C)$ & 5.04 & 5.28 & 6.93 & 6.81 & 6.05 & 6.10 & 6.01 & 6.09 & 5.38 & 5.45 \\
\hline
\end{tabular}

Units are mdyn $\AA^{-1}$ for stretching

${ }^{\text {a }}$ This work

${ }^{\mathrm{b}}$ From Ref[40]

${ }^{\mathrm{c}}$ From Ref[37]

${ }^{\mathrm{d}}$ From Ref[42]

${ }^{\mathrm{e}}$ From Ref[38]

\section{Conclusions}

In this study, the optimized structure and vibrational infrared of synthetic cyclohexenecarboxylate ester antiviral Oseltamivir $(\mathrm{O})$ in gas phase and aqueous solution were elucidate by using B3LYP/6-311++ $\mathrm{G}^{* *}$ level of DFT. The optimized most stable theoretical structures determined in both media show very excellent agreement with those experimental reported for Oseltamivir phosphate. The solvation energy value of $(\mathrm{O})$ in water $(-127.37 \mathrm{~kJ} / \mathrm{mol})$ is between the predicted for antiviral Idoxuridine $(-124.50 \mathrm{~kJ} / \mathrm{mol})$ and Ribavirin $(-141.85 \mathrm{~kJ} / \mathrm{mol})$, and it is slightly higher than Oseltamivir phosphate. Besides, (O) containing a $\mathrm{NH}_{2}$ group and a $\mathrm{NH}$ group reveals lower solvation energy as compared with other antiviral agents with an $\mathrm{NH}_{2}$ group, such as Ribavirin, Cidofovir and Brincidofovir. Atomic MK, NPA, and Mulliken charges reveal different behaviours on the $\mathrm{N}$ and $\mathrm{O}$ atoms of acceptors and donor groups in both gas and water media, while the NBO results show higher stability of (O) in solution due to five types of donor-acceptor interactions observed in this medium. This latter resulted agrees with lower reactivity evidenced in solution. The frontier orbital studies have revealed that $(\mathrm{O})$ in gas phase has a very similar gap value to antiviral Cidofovir used against the ebola disease, while Chloroquine in the two media are most reactive than $(\mathrm{O})$. Now, Oseltamivir can be easily identified by using vibrational spectroscopy because the assignments of 144 vibration normal modes have been done using the harmonic force fields calculated with the SQMFF procedure. Scaled force constants for $(\mathrm{O})$ in the mentioned media are also reported for first time. The calculations in solution predicted shifting of IR bands due to vibration modes of $\mathrm{C}=\mathrm{O}$ and $\mathrm{NH}_{2}$ groups as a result of hydration of these groups with water molecules. Besides, the mapped electrostatic potential surfaces have evidenced that carbonyl group and imino/amino groups are the favourable sites for reactions of Oseltamivir with electrophil and nucleophil potentials biological reactive. Hence, knowing these reaction sites in the future, molecular docking calculations could be carried out to investigate antiviral properties by using structures of COVID-19: 6LU7, 6M03, 6W63, and 7BTF.

Supplementary Information The online version contains supplementary material available at https://doi.org/10.1007/s00894-021-04962-3.

Acknowledgements The author would like to thank Prof. Tom Sundius for his permission to use MOLVIB.

Author contribution Mohammad Vakili: Formal analysis and investigation, Elida Romano: Conceptualization, Methodology, Vahidreza Darugar: Conceptualization, Methodology, Silvia Antonia Brandán: Writing, original draft preparation, review, editing and Supervision.

Funding This work was supported with grants from CIUNT Project No. 26/D608 (Consejo de Investigaciones, Universidad Nacional de Tucumán).

Data availability Available when the authors require it.

Code availability Not applicable.

\section{Declarations}

Conflict of interest The authors declare no competing interests.

\section{References}

1. Lindegårdh N, Hien TT, Farrar J, Singhasivanon P, White NP, Day NPJ (2006) A simple and rapid liquid chromatographic assay for 
evaluation of potentially counterfeit Tamiflu®. J Pharm Biomed Anal 42(4):430-433

2. Joseph-Charles J, Geneste C, Laborde-Kummer E, Gheyouche R, Boudis H, Dubost J-P (2007) Development and validation of a rapid HPLC method for the determination of Oseltamivir phosphate in Tamiflu ${ }^{\circledR}$ and generic versions. J Pharm Biomed Anal 44:1008-1013

3. Aydoğmuş Z (2009) Simple and sensitive spectrofluorimetric method for the determination of Oseltamivir phosphate in capsules through derivatization with fluorescamine. J Fluoresc 19:673-679

4. Laborde-Kummer E, Gaudin K, Joseph-Charles J, Gheyouche R, Boudis H, Dubost J-P (2009) Development and validation of a rapid capillary electrophoresis method for the determination of Oseltamivir phosphate in Tamiflu ${ }^{\circledR}$ and generic versions. J Pharm Biomed Anal 50:544-546

5. Dharan NJ, Gubareva LV, Meyer JJ, Okomo-Adhiambo M, McClinton RC, Marshall SA, St George K, Epperson S, Brammer L, Klimov AI, Bresee JS, Fry AM (2009) Infections with Oseltamivir-Resistant Influenza A(H1N1) virus in the United States. J A Med Assoc 301:1034-1041

6. Moscona A (2009) Global Transmission of Oseltamivir-resistant influenza. N Engl J Med 360:953-956

7. Hurt AC (2010) Nor'e SS, McCaw JM, Fryer HR, Mosse J, McLean AR, Barr IG, Assessing the viral fitness of Oseltamivirresistant influenza viruses in ferrets, using a competitive-mixtures Model. J Virol 84:9427-9438

8. Duan S, Boltz DA, Seiler P, Li J, Bragstad K, Nielse LP, Webby RJ, Webster RG, Govorkova EA (2010) Oseltamivir-resistant pandemic H1N1/2009 influenza virus possesses lower transmissibility and fitness in ferrets. PLoS Pathog. 6:e1001022

9. Bunaciu AA, Nita S, Fleschin Ş, Aydoğmuş Z, Aboul-Enein HY (2012) A Fourier transform infrared spectrophotometry method used for Oseltamivir determination in pharmaceutical formulations. GU J Sci 25(3):631-634

10. Vishkaee TS, Mohajerani N, Nafisi S (2013) A comparative study of the interaction of Tamiflu and Oseltamivir carboxylate with bovine serum albumin. J Photochem Photobiol, B 119(5):65-70

11. Siddiqui A, Shah RB, Khan MA (2013) Oseltamivir phosphateamberlite ${ }^{\text {TM }}$ IRP 64 ionic complex for taste masking: preparation and chemometric evaluation. J Pharmaceutical Sciences 102(6):1800-1812

12. Górecki M (2015) Configurational and conformational study of (-)-Oseltamivir using a multi-chiroptical approach. Org Biomol Chem 13(10):2999-3010

13. Li Y, Lin Z, Guo M, Xia Y, Zhao M, Wang C, Xu T, Chen T, Zhu B (2017) Inhibitory activity of selenium nanoparticles functionalized with Oseltamivir on H1N1 influenza virus. Int J Nanomed 12:5733-5743

14. Hajzer V, Fišera R, Latika A, Durmis J, Kollár J, Frecer V, Tučeková Z, Miertuš S, Kostolanský F, Varečková E, Šebesta R (2017) Stereoisomers of Oseltamivir - synthesis, in silico prediction and biological evaluation. Org Biomol Chem 15:1828-1841

15. Willett DR, Rodriguez JD (2018) Quantitative Raman assays for on-site analysis of stockpiled drugs. Anal Chim Acta 1044:131-137

16. Eom G, Hwang A, Lee DK, Guk K, Moon J, Jeong J, Jung J, Kim B, Lim E-K, Kang T (2019) Superb specific, ultrasensitive, and rapid identification of the Oseltamivir-resistant $\mathrm{H} 1 \mathrm{~N} 1$ virus: naked-eye and SERS dual-mode assay using functional gold nanoparticles. ACS Appl Bio Mater 2:1233-1240

17. Eom G, Hwang A, Kim H, Yang S, Lee DK, Song S, Ha K, Jeong J, Jung J, Lim E-K, Kang T (2019) Diagnosis of Tamiflu-resistant influenza virus in human nasal fluid and saliva using surfaceenhanced Raman scattering. ACS Sens 4(9):2282-2287
18. Li YH, Lin ZF, Zhao MQ et al (2016) Silver nanoparticle based codelivery of Oseltamivir to inhibit the activity of the H1N1 influenza virus through ROS-mediated signaling pathways. ACS Appl Mater Interfaces 8(37):24385-24393

19. Patel TS, Cinti S, Sun D, Li S, Luo R, Wen B, Gallagher BA, Stevenson JG (2017) Oseltamivir for pandemic influenza preparation: maximizing the use of an existing stockpile. Am J Infect Contr 45(3):303-305

20. Becke AD (1988) Density-functional exchange-energy approximation with correct asymptotic behavior. Phys Rev A 38:3098-3100

21. Lee C, Yang W, Parr RG (1988) Development of the Colle-Salvetti correlation-energy formula into a functional of the electron density. Phys Rev B 37:785-789

22. Pulay P, Fogarasi G, Pongor G, Boggs JE, Vargha A (1983) Combination of theoretical ab initio and experimental information to obtain reliable harmonic force constants Scaled quantum mechanical (QM) force fields for glyoxal acrolein butadiene formaldehyde and ethylene. J A Chem Soc 105:7073

23. Rauhut G, Pulay P (1995) Transferable scaling factors for density functional derived vibrational force fields. J Phys Chem 99:3093-3099

24. Rauhut G, Pulay P (1995) Transferable scaling factors for density functional derived vibrational force fields. J Phys Chem 99:14572

25. Sundius T (2002) Scaling of ab-initio force fields by MOLVIB. Vib Spectrosc 29:89-95

26. Miertus S, Scrocco E, Tomasi J (1981) Electrostatic interaction of a solute with a continuum. Chem Phys 55:117-129

27. Tomasi J, Persico J (1994) Molecular interactions in solution: an overview of methods based on continous distributions of the solvent. Chem Rev 94:2027-2094

28. Marenich AV (2009) Cramer CJ, Truhlar DG, Universal solvation model based on solute electron density and a continuum model of the solvent defined by the bulk dielectric constant and atomic surface tensions. J Phys Chem B 113:6378-6396

29. Karrouchi K, Brandán SA, Sert Y, El-marzouqi H, Radi S, Ferbinteanu M, Faouzi MEA, Garcia Y, Ansar M (2020) Synthesis X-ray structure Vibrational spectroscopy DFT investigation and biological evaluation studies of (E)-N'-(4-(dimethylamino) benzylidene)-5-methyl-1H-pyrazole-3-carbohydrazide. J Mol Struct 1219:128541

30. Karrouchi K, Brandán SA, Sert Y, El-marzouqi H, Radi S, Ferbinteanu M, Garcia Y, Ansar M (2021) Synthesis structural molecular docking and spectroscopic studies of (E)N'-(4-methoxybenzylidene)-5-methyl-1H-pyrazole-3-carbohydrazide. J Mol Struct 1228:129714

31. El Kalai F, Karrouchi K, Baydere C, Daoui S, Allali M, Dege N, Benchat N, Brandán SA (2021) Synthesis crystal structure spectroscopic studies NBO AIM and SQMFF calculations of new pyridazinone derivative. J Mol Struct 1223:129213

32. Romano E, Issaoui N, Manzur ME, Brandán SA (2020) Properties and molecular docking of antiviral to COVID-19 chloroquine combining DFT calculations with SQMFF approach. International Journal of Current Advanced Research 9(8A):22862-22876

33. Romani D, Noureddine O, Issaoui N, Brandán SA (2020) Properties, reactivities and molecular docking of potential antiviral to treatment of COVID-19 niclosamide in different media. Biointerface Research in Applied Chemistry 10(6):7295-7328

34. Veber DF, Johnson SR, Cheng H-Y, Brian R, Ward KW, Kopple KD (2002) Molecular properties that influence the oral bioavailability of drug candidates. J Med Chem 45:2615-2623

35. Lipinski CA, Lombardo F, Dominy BW, Feeney PJ (2001) Experimental and computational approaches to estimate solubility and permeability in drug discovery and development setting. Adv Drug Deliv Rev 46:3-26

36. Romani D, Brandán SA (2019) Effect of the side chain on the properties from cidofovir to brincidofovir, an experimental 
antiviral drug against to Ebola virus disease. Arab J Chem 12:2959-2972

37. Romani D, Márquez MJ, Márquez MB, Brandán SA (2015) Structural, topological and vibrational properties of an isothiazole derivatives series with antiviral activities. J Mol Struct 1100:279-289

38. Romani D, Brandán SA (2017) Investigating the structural and vibrational properties of the nucleoside reverse transcriptase inhibitor emtricitabine. International Journal of Science and Research (IJSR) 8:1

39. Brandán SA (2017) Structura topological electronic and vibrational properties of the antiviral trifluridine agent Their comparison with thymidine. Paripex A Indian Journal of Res 6(10):346-36

40. Romani D, Brandán SA (2017) Spectroscopic and structural study of the antiviral agent idoxuridine by using DFT and SCRF calculations. Int J Sci Res (IJSR) 8(1):66-86

41. Ladetto MF, Márquez MJ, Romani D, Brandán SA (2019) Structural and vibrational studies on isomers of antiviral ribavirin drug in gas and aqueous environmental by using the SQM approach. J Adv Chem 16:6325-6353

42. Iramain MA, Brandán SA (2018) Structural and vibrational study on the acid, hexa-hydrated and anhydrous trisodic salts of antiviral drug Foscarnet. Drug Des Int Prop Int J 1(3):1-17

43. Checa MA, Rudyk RA, Chamorro EE, Brandán SA, Chapter 1, Structural and vibrational properties of a reverse Inhibitor against the HIV Virus, Dideoxynucleoside Zalcitabine in gas and aqueous solution phases, pg. 1-26, Edited Collection, Nova Science Publishers, Inc. (2015).

44. Frisch J, Trucks GW, Schlegel HB, Scuseria GE, et al., Gaussian 09, Revision A.02, M. Gaussian, Inc., Wallingford CT, 2009.

45. Ugliengo P (1998) MOLDRAW Program. University of Torino, Dipartimento Chimica IFM, Torino, Italy

46. Glendening ED, Badenhoop JK, Reed AD, Carpenter JE, Weinhold F, NBO 3.1; Theoretical Chemistry Institute, University of Wisconsin; Madison, WI, 1996.
47. Bader RFW, Atoms in molecules, a quantum theory, Oxford University Press, Oxford, 1990, ISBN: 0198558651

48. Biegler-Köning F, Schönbohm J, Bayles D (2001) AIM2000; A program to analyze and visualize atoms in molecules. J Comput Chem 22:545

49. Besler BH (1990) Merz Jr, KM Kollman P, Atomic charges derived from semiempirical methods. J Comp Chem 11:431-439

50. Nielsen AB, Holder AJ, Gauss View 5.0, User's reference, GAUSSIAN Inc., Pittsburgh, PA, 2008.

51. Brandán SA (2021) Normal internal coordinates Force fields and vibrational study of species derived from antiviral adamantadine. Int J Quantum Chem 121(2):e26425

52. Ditchfield R (1974) Self-consistent perturbation theory of diamagnetism. I. A gage-invariant LCAO (linear combination of atomic orbitals) method for NMR chemical shifts. Mol Phys 27:714-722

53. Keresztury G, Holly S, Besenyei G, Varga J, Wang AY, Durig JR (1993) Vibrational spectra of monothiocarbamates-II IR and Raman spectra vibrational assignment conformational analysis and ab initio calculations of S-methyl-N N-dimethylthiocarbamate Spectrochim. Acta 49A:2007-2026

54. Górecki M (2015) (A configurational and conformational study of (-)-Oseltamivir using a multi-chiroptical Approach. Org Biomol Chem 13:2999

55. Naumov P, Yasuda N, Rabeh WM, Bernstein J (2013) (The elusive crystal structure of the neuraminidase inhibitor Tamiflu (Oseltamivir phosphate): molecular details of action. Chem Commun 49:1948-1950

56. Parr RG, Pearson RG (1983) Absolute hardness: companion parameter to absolute electronegativity. J Am Chem Soc 105:7512-7516

Publisher's note Springer Nature remains neutral with regard to jurisdictional claims in published maps and institutional affiliations. 